\title{
"Ivory craftsmanship, trade and social significance in the southern Iberian Copper Age: the evidence from the PP4- Montelirio sector of Valencina de la Concepción (Seville, Spain)."
}

\author{
García Sanjuán, Leonardo \\ Luciañez Triviño, Miriam \\ Schuhmacher, Thomas $\mathrm{X}$. \\ Wheatley, David \\ Banerjee, Arun
}

\section{Introduction}

Because of its great potential to provide data on contacts and overseas trade, ivory has aroused a great deal of interest since the very start of research into lberian Late Prehistory. One of the first scholars to bring attention on this material was Estació da Veiga, who suggested that there were finished items and pieces of raw ivory imported from North Africa to be found in southern Iberia (Da Veiga, 1886-1891, vol. 1, p. 268270; vol. 2, p. 212). For his part, Luis Siret, who differentiated between items made from elephant or hippopotamus ivory, put forward Egypt as the place from where finished objects were imported (Siret, 1912:33). Later, J.C. Serra Rafols argued that, since there were no substantial reasons for believing Egypt to be the source of supply for ivory found in Iberia, north-west Africa was the main candidate (Serra Ràfols, 1925: 87). At around the same time, A. Götze denied a use of local fossilized ivory, because he thought it to be too fragile and brittle (Götze, 1925: 87). Some years later, in their monumental work about Iberian megalithic tombs, the Leisners compiled a list of ivory objects that is still a major resource for research (Leisner \& Leisner, 1943). Regarding the origins, A. Jodin and G. Camps connected the finds of Iberian ivory with the appearance of Bell Beakers in North West Africa (Jodin 1957; Camps 1960), a view that would be expanded in A. Gilman's and R. Harrison's now classic paper on Copper Age and Early Bronze Age exchange networks in the western Mediterranean (Harrison and Gilman, 1977).

The first modern monographic studies on Iberian prehistoric ivory focused on Iron Age objects connected to Phoenician colonisation (Aubet Semmler, 1979; 1980; 1982). Apart from occasional papers appearing in the 1980s and 1990s (Spindler, 1981; Fonseca Ferrandis, 1988; Poyato Holgado and Hernando Grande, 1988; Pascual Benito, 1995), the recent boom in research into the significant presence of ivory objects in contexts dated to the $3^{\text {rd }}$ and $2^{\text {nd }}$ millennia BCE has arisen from two consecutive research projects carried out by the German Archaeological Institute in Madrid (undertaken between 2005 and 2008, and between 2009 and 2012 respectively). These projects have provided valuable, innovative contributions to the study of ivory in the Early Bronze Age (C. 2200-1500 cal BCE), mainly in the south-east of the Iberian 
Peninsula (Pascual Benito, 2012; López Padilla, 2006; 2009; 2012; Barciela González, 2012; Liesau Von Lettow and Schuhmacher, 2012; Schuhmacher, 2012; in press).

Nonetheless, the most spectacular finds belong to the ivory from the Copper Age (c. 3200-2200 cal BCE), an area in which research has advanced at a remarkable pace, as shown by the publication of several papers that reveal the outstanding scale and socioeconomic significance that the use of ivory had throughout southern Iberia (Cardoso, 1995; 2004; Schuhmacher and Cardoso, 2007; Valera, 2009; Schuhmacher et al., 2009; 2012; 2013; Cardoso and Schuhmacher, 2012; Schuhmacher and Banerjee, 2012; Liesau Von Lettow and Moreno, 2012; Vargas Jiménez et al., 2013). The recent expansion of this field of research is providing highly valuable evidence for investigating crucial aspects of the dynamics of social complexity that play a central role in Iberian Copper Age research, including long-distance trade, craft specialisation and the role of luxury items in the exhibition of status and power.

One of the archaeological sites that are contributing the most data for analysing ivory from the Copper Age in southern Iberia is Valencina de la Concepcion (Seville), a wellknown settlement located near Sevilla (Figure 1) which is currently the focus of several debates on the development of social complexity. This applies in particular to the scale of agricultural and metallurgical production, functional specialisation, monumentality and social inequality - for contributions in English to these debates, see Nocete Calvo et al., 2008; Costa Caramé et al., 2010; Inacio et al., 2011; Wheatley et al., 2012; García Sanjuán and Murillo Barroso, 2013; Rogerio-Candelera et al., 2013; etc. Recent studies on Valencina's ivory have suggested the high degree of technical skill and specialisation reached in the working of this raw material, which has been proven to come from North Africa and Asia (Vargas Jiménez et al., 2012; Nocete Calvo et al., 2013).

This article makes a significant contribution to this line of research by providing new, unpublished evidence and examining the significance of ivory craftsmanship in commercial, social and ideological terms. It also assesses in greater detail the prominent part played by luxury ivory items as an expression of social status and power. More specifically, this paper presents the study of several extraordinary ivory objects from sector PP4-Montelirio of the Valencina de la Concepción site, excavated between 2007 and 2008. In this sector, 134 Copper Age structures were revealed (also some Roman); 61 contained human remains and, consequently, were classed as funerary, while 73 did not contain human remains and were classified as non-funerary (Mora Molina et al., 2012). The artefacts studied here come from structure 1004210049 , for which some studies on its unique contents have already been published, including and analysis of the human remains (Robles Carrasco and Díaz-Zorita Bonilla, 2012), an exceptional piece of amber (Murillo-Barroso and García Sanjuán, 2012) and the red pigments (Rogerio-Candelera et al., 2013).

Structure 10042-10049 from PP4-Montelirio is a megalithic funerary construction with two chambers (Figure 2). There is an access corridor with a maximum length of $12 \mathrm{~m}$ and maximum width of $0.70 \mathrm{~m}$, bounded by 55 slate slabs ( 28 on the north side and 26 on the south side) with another 13 inside. This leads into the first chamber, whose maximum diameter is $2.57 \mathrm{~m}$, and which was partially destroyed by work carried out in 
1998 in this sector of the site. The remains of four people were identified between the access corridor and first chamber, together with over 2000 perforated beads with red pigment, four fragments from one or two small pottery figurines, fragments of 12 stone arrow heads, three fragments flint blade, several carved remains from various ivory objects (very broken), some decorated), as well as two examples of marine malacofauna and fragments of deer antlers.

Leading from the first chamber is a second corridor, $2.52 \mathrm{~m}$ maximum length and 0.51 $\mathrm{m}$ maximum width, bounded by 14 slate slabs ( 7 on the north side and 8 on the south side), joining the first chamber to second. The second chamber, which is better preserved than the first, has a maximum diameter of $2.16 \mathrm{~m}$ and is enclosed by 23 slabs. Two stratigraphic levels were found in the second chamber.

- The lower one (Figure 3) contained a primary individual burial in foetal position, lying on the right side and the head pointing to the corridor, which was covered in several parts with red pigment made from cinnabar (Rogerio-Candelera et al., 2013). An unworked elephant tusk (described below) was found framing the head of this individual, who had also been furnished with a set of grave goods including a large borde almendrado (almond-rim) plate partly covered in red pigment, a set of 23 flint blades, numerous ivory objects (many decorated and quite fragmented), a flint dagger blade found next to an amber pommel, probably from Sicily (Murillo-Barroso and García Sanjuán, 2012), and a small, morphologically unrecognisable copper object.

- The upper level of this chamber (Figure 3) was physically separated from the lower deposit by 22 slate slabs laid horizontally and had no human remains. Several objects were found here, including five pots, a rock crystal dagger blade; a set of 38 flint blades and fragments of 16 others, a flint arrow-head, several ivory objects (some of which are described in this article), 90 beads, an ostrich eggshell, etc.

In total, with over 50 objects found in the first chamber and access corridor and about 100 in the second chamber (more than 30 items in the lower level and over 70 in the upper), structure 10042-10049 yielded some 150 objects, in some cases worked with foreign raw materials (such as the amber, cinnabar and ivory, also the ostrich egg), which together with the architecture of the grave and its position in respect of the others, suggests that the people buried there enjoyed high social status. The 22 ivory objects identified from this grave represent $56.4 \%$ of the total recovered from sector PP4-Montelirio (39 pieces), although this count will probably increase as their study progresses ${ }^{1}$. Although it is not the Chalcolithic funerary structure containing the most ivory objects found in Iberia, structure 10042-10049 certainly held the largest quantity in gross weight.

Among the 39 ivory artefacts identified in the PP4-Montelirio sector are bracelets, hairpins, various types of containers, two elephant tusks (one unworked and the other

\footnotetext{
${ }^{1}$ Future restoration work maybe cause this figure to change.
} 
with carved decoration), plaques, a dagger hilt and part of what may be its sheath, a pair of combs or ornamental combs, and remains of other, unidentifiable objects. All these objects were found in poor condition; in addition, the excavation of some of them had to be completed in the Museum of Sevilla, where they are currently kept, as this was not finished during the field work stage. For their study, the objects described below have been subjected to a six-month period of conservation and restoration that included cleaning and consolidation, as well as a laborious re-assembling ${ }^{2}$.

\section{New evidence from structure 10042-10049}

\section{2.a. Unworked elephant tusk}

This exceptional piece comes from the second chamber in structure 10042-10049. It was found in stratigraphic unit 664, or base level (or lower), where a single person was buried: a male aged between 17 and 25 years (Robles Carrasco, 2011: 15-16) heavily covered in red pigment (cinnabar). The tusk was found on the eastern side of the chamber, with the concave side facing the head of the skeleton, as though "framing" the head and separating the body from the threshold between the chamber and the corridor.

The whole tusk weighs $1,170.5 \mathrm{~g}$ and is about $59-60 \mathrm{~cm}$ long (Figure 5). It is not worked and completely undecorated, but was cut horizontally into three parts similar in size and weight. Until now, no references to similar cases of complete unworked tusks have been published for Iberian Copper Age, although in large megalithic constructions in Montelirio (Fernández Flores and Aycart Luengo, 2012) and Matarrubilla (Collantes de Terán, 1969), at Valencina de la Concepcion itself, and in one of the graves at El Kiffen (Dar Bouaza, Morocco) (Bailloud-Mieg, 1964: 170f fig. 19) tusk segments were also found as part of grave goods. To our knowledge, therefore, this is the largest example of unworked raw ivory ever found in Iberian Late Prehistory.

\section{2.b. Carved vessel}

This piece comes from stratigraphic unit 664 (base level, or lower) in the second chamber of structure 10042-49, thus forming part of the grave goods of the male individual described above. It is a cylindrical vessel $6 \mathrm{~cm}$ high and $7.05 \mathrm{~cm}$ average diameter. The wall gradually thins out from the base $(1 \mathrm{~cm}$ thick) to the edge $(0.2 \mathrm{~cm})$. The base is $1.2 \mathrm{~cm}$ thick. The vessel was made from part of an elephant tusk and decorated on the outside only, in a combination of several motifs: three parallel lines run horizontally around the edge, while the remaining surface is chequered in relief, with a four-sided pyramid on each square (Figures 6 and 7).

From its shape, it seems obvious that this piece is a vessel or container for both liquids and solids. This type of container made of ivory, bone or stone have been found at

\footnotetext{
${ }^{2}$ Except for the raw ivory tusk, which was restored by the Sevilla Archaeology Museum staff, the other four items described in this paper (vessel, carved tusk, hilt and sheath) were treated by Miriam Luciáñez Triviño (Luciañez Triviño, 2012).
} 
Copper Age sites of Estremadura and Alentejo (Portugal) and Extremadura, the Guadalquivir basin and the Southeast (Spain). Ivory containers with the same decoration as the one described here have been found at the Copper Age sites of Tituaria, Praia das Maçãs, Vila Nova de São Pedro and Perdigões in Portugal, as well as in La Pijotilla, Cañada Honda B, Cueva de las Ventanas, Los Millares Tomb 7 and La Sabina 96 in Spain (Schuhmacher, in press). One important consideration is, however, that containers in which base and wall are made out of the same piece, like the PP4Montelirio example described here, have only been found in Perdigões ${ }^{3}$ (Lago et al., 1998; Valera, 2000) and, outside Iberia, in Rouazi-Skhirat (Morocco) (Daugas, 2002; Bokbot, 2005: figs. 27 and 28).

\section{C. Carved elephant tusk}

This exceptional artefact comes from stratigraphic unit 535 of the second chamber in structure 10042-10049, corresponding to the upper (later) deposit layer where no human remains were found. This object was found on the right side of the chamber (northern side), as seen when entering from the corridor, approximately $1.30 \mathrm{~m}$ from the chamber entrance and about $20 \mathrm{~cm}$ from the wall.

It is an elephant tusk, or part of it, decorated on the outside and hollow in the interior. At present, it is approximately $30 \mathrm{~cm}$ long with an average diameter of the preserved part of $4.25 \mathrm{~cm}$. It could not be fully re-assembled, but according to photographs from the field work, the piece may have originally been 36 or $37 \mathrm{~cm}$ long. The design consists of strips interspersed with various decorative motifs: series of parallel lines, with chequered strips in relief (with a four-sided pyramid on each square) set in between. The tip, or distal end, is finished off with a globular protuberance of a shape that resembles an acorn (Figures 8, 9 and 10). This piece appears to be worked by following the natural shape of an elephant tusk. The interior was hollowed out, and the outside was worked and decorated in the same way as the vessel described above. The piece is broken at the "acorn", exposing the fact that it is completely hollow from the mouth, or widest part, to the tip. During the study, a feature appearing to be a perforation in one side of the protuberance was observed, which could have been made with a drill. However, whether this perforation was the result of a deliberate drilling or part of an accidental cracking could not be ascertained, due to the fracture described above. As with the previous piece, it still preserves a shiny, polished surface in some areas.

From its shape, and in the same way that horns are used as vessels, it may be thought that this object might have been used as a container for liquids or solids. In addition, if the perforation at the tip is proved, it may have been used as a drinking vessel (similar to a wineskin).

In contexts of the Copper Age in southern Iberia, objects of a similar shape, to a certain extent, have been documented and interpreted as "idols" or "betils", which are usually

\footnotetext{
${ }^{3}$ One of us (T. X. Schuhmacher) is currently studying the objects from Perdigões which remain mostly unpublished at the time of writing these lines.
} 
elongated and tapered, and which very often are wider at one than the other and finished off either with a rounded or pointed tip, or in a ball shape (Almagro Gorbea, 1973: 63). However, these are made of stone, not ivory. Recently, a similar item, made from a hollowed out elephant tusk, was found in La Molina (Lora de Estepa, Seville), which is about $120 \mathrm{~km}$ east of Valencina. However, this object is rather smaller and rougher than the one from PP4-Montelirio, and the surface is only partly decorated, although the proximal end is decorated with a strip of parallel cuts, and the tip is carved in the same globular shape (Juárez Martín, 2010: 91).

\section{2.d.- Carved dagger hilt}

This piece comes from stratigraphic unit 535, in the upper (later) deposit layer in the second chamber of structure 10042-10049. It was found in the south side of the chamber (on the left of the entrance), where most of the objects in this stratigraphic unit were found, at less than $1 \mathrm{~m}$ from the chamber entrance and near the wall. Although several hypotheses were initially put forward to interpret this piece (amulet, idol or rod of office, among others), an analysis of photographs taken in the field eventually established that it was the hilt to a rock crystal blade found with a clear spatial connection.

Therefore, this piece forms a functional whole with the rock crystal blade and plaque described in the following section, which is interpreted as being part of the dagger sheath. The hilt comprises two parts worked separately and then assembled to each other: a pommel or ornamental top (between 12 and $13 \mathrm{~cm}$ from point to point, $1 \mathrm{~cm}$ thick and about $4.5 \mathrm{~cm}$ wide) and a hilt $(8.4 \mathrm{~cm}$ long, $4.5 \mathrm{~cm}$ wide and approximately 1 $\mathrm{cm}$ thick) (Figures 11, 12 and 13).

- The pommel has eight slightly conical projections on what is thought to be the front side, while the rear side has 14 perforations around the edge. The photographs from the field show that at the side, very close to the perforations of this pommel, there was a set of perforated beads in a bunch, which makes us suspect that perhaps these were also part of the decoration for the piece and were set into the 14 holes. The pommel had been carefully hollowed at the base, so that it could be fitted to the upper part of the hilt.

- The hilt is richly decorated on both sides in zigzag lines carved in relief, with the points almost touching to create rhomboid shapes, slightly raised in the centre. The left and right edges are finished in a series of 3 or 4 parallel lines making a $0.5 \mathrm{~cm}$ border on each face. The sides are not decorated. The hilt has a hollow at the distal end where the rock crystal blade was inserted and held.

In southern Iberia there are dagger hilts or ornamental tops for hilts made in ivory (e. g. several examples from Perdigões), but they are much simpler, usually undecorated and none features the kind of crescent shape present in the item studied here. At the great megalithic monument of Matarrubilla, which is part of the Valencina de la Concepcion settlement, a knife handle and an object that might be a penknife handle were found (Collantes de Terán, 1969:58). Worth mentioning is also the case of La 
Molina artificial cave, were a slightly tapered object was found, which the excavators were certain to be "... a handle or hilt, as it had a flint blade fitted to the narrowest end" (Juárez Martín, 2010: 91). In Perdigões, a pommel in crescent form was found, but with the crescent pointing the other way round than the piece of Valencina.

In fact, the archaeological record for Iberian or European Later Prehistory does not, so far, record any similar ivory object. The shape of the piece harks back to the "crescentshaped" items found in Bronze Age stelae in southern Portugal, which normally appear hanging from the "shoulders" or "neck" of the stone/stela/anthropomorph. The "crescent-shaped" object is one of the basic motifs forming the iconography of these stelae (Díaz-Guardamino, 2009: 300), and shows a clear iconographic prominence in some of these, which would emphasise its symbolic value, perhaps as a symbol of power and/or social status. In some of the crescent-shaped representations on the Alentejan stelae, the object is clearly portrayed as consisting of two parts, with a pommel and hilt, exactly like the PP4-Montelirio piece described above. Therefore, it is possible that the "crescent-shaped" objects symbolised on the stele represent similar objects to those found in grave 10042-10049. Similarly shaped hilts also appear in large numbers in cave paintings in the Valcamonica valley in Italy.

\section{2.e. Carved plaque or sheath}

This piece also comes from stratigraphic unit 535, from the upper (later) deposit layer in the second chamber of structure 10042-10049. It was found only a few centimetres from the hilt described above and the rock crystal blade.

It is a decorated plaque between 0.4 and $0.6 \mathrm{~cm}$ thick, and in its current condition, is $25 \mathrm{~cm}$ long $^{4}$. The rounded end, which we take to be the proximal narrows as it approaches the opposite, or distal, end (very fragmented and incomplete). It is carved in relief on one side only (which we take to be the reverse) in zigzag lines almost touching at the points, as with the hilt decoration, but on a larger scale (Figures 14 and 15). The undecorated or obverse side is done on two levels, as the two lower thirds have rims on the left and right (which are thicker than the centre of the plaque), which must have acted as a stop and support for the hilt pommel, since the arch of the pommel and the proximal end of the plaque meet exactly at this point (Figures 16). On both lateral rims there are several V-shaped perforations (a pair of perforations that meet inside the piece). The left side has one perfectly preserved and four fragmented $\mathrm{V}$-shaped perforations, and the right side has four fragmented of these perforations.

This object appears to have been extracted in a single piece. Therefore, the tusk must have been larger than $14 \mathrm{~cm}$ in diameter (which is the measurement of the widest part of the plaque). The manufacturing process must have followed the same stages as with the other pieces: a first rough plaque was cut, thicker than the end product, the surface smoothed, the design for the decoration drawn on the surface and, finally, carved and polished.

\footnotetext{
${ }^{4}$ Despite the extensive destruction this item has undertaken, the field photographs suggest that originally it would have been much longer.
} 
The shape is similar to other pieces known in for the southern Iberian Copper Age record, which from lack of a better knowledge of their function, have been described as "sandal soles" or "sandal-shaped idols". To be exact, pieces of this type, made in bone or stone, with perforations (not V-shaped) have been described for Almizaraque (Almería, Spain) (Maicas Ramos, 2007: Fig. III. 74) and Alapraia (Estremadura, Portugal) (Gonçalves et al., 2005: 183, 185). The piece from grave 12 at Los Millares (Almeria, Spain) made from Asian ivory, is more similar (Leisner \& Leisner, 1943: 25 lam. 11, 20; Schuhmacher, in press). For the case at hand, its position in relation to the dagger hilt described above, and because of its shape, it seems certain that it is part of the dagger sheath or case. If this were so, the sheath would have been made in two parts from two different materials: on one hand, a rigid ivory plate, and on the other, cloth or leather (which was not preserved) which would have been sown to the plaque via the V-shaped perforations (Figure 17).

\section{3.- Scientific analysis}

\section{3.a.- Characterisation and provenancing.}

As part of the research project mentioned above, Dr. A. Banerjee and his Mainz University team have successfully analysed 130 Iberian ivory objects (including a number of them from Valencina) and 17 from Morocco. Various analytical techniques have been used in order to determine the raw material used, including measurement of the Schreger angle by optical microscopy, Fourier Transformed Infrared (FTIR)Spectroscopy, elemental analysis and Isotopic Ratio Mass Spectrometry (Banerjee et al., 2011a; 2011b; Banerjee and Huth, 2012; Nocete Calvo et al., 2013).

Following the results of the analysis (Tables 1 and 2; Figures 18 and 19), it has been established that all four objects from tomb 10042-10049 were made of ivory from Asian Elephant (Elephas maxiums) while the complete unworked tusk belongs to an African Savannah Elephant (Loxodonta africana africana). This is therefore the first time that ivory from both Asian and African elephants is found in one and the same grave context.

\section{3.b.- C14 dating}

Five ivory samples, each one obtained from one of the objects described above, where sent for radiocarbon dating at the AMS dating facility of Friedrich-Alexander University of Erlangen-Nürnberg (Germany). The results obtained (Table 3) show that four of the five dates are totally incoherent with the chronological and cultural context of structure 10042-10049. According to Dr. Scharf, chief technician of the FriedrichAlexander University laboratory, all samples had very little carbon and no nitrogen. The only one that provided a Copper Age date (Erl-17299) was that with the highest level of carbon: this sample, corresponding to the hilt, was dated in $3905 \pm 74$ BP (2575-2197 cal BCE 2 $\sigma$ ). This date is not very consistent with two other C14 dates obtained from this tomb (see discussion below). However, given the problematic nature of the samples, the date is regarded by us as not fully reliable. 


\section{4.- Discussion}

The five pieces described above, and the analytical data obtained from them, provide valuable data about the technical specialisation, long-distance exchange and ideological value of ivory objects in Copper Age Iberian. Prior to this, however, the question of chronology must be briefly addressed.

As explained above, four of the C14 dates taken from ivory objects have given wrong results. The only date that relates to the Copper Age is Erl-17299 (2575-2197 cal BCE $2 \sigma)$. Two other $\mathrm{C} 14$ dates were obtained from the human bones identified in the antechamber and first chamber of structure 10042-10049. These dates are placed in 3007-

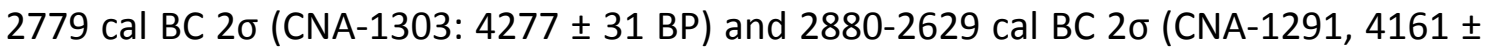
$34 \mathrm{BP}$ ) respectively, that is to say, in the first part of the $3^{\text {rd }}$ millennium $B C E$. This chronology is basically coincident with that obtained from the neighbouring great megalithic monument of Montelirio. Unfortunately, the two attempts made to obtain radio-carbon dates from samples of the bones of the person buried at the base level of the main chamber of structure 10042-10049 have been fruitless, due to the absence of collagen.

If, for the sake of the argument, the date obtained for the ivory hilt found in the upper level of the main chamber (2575-2197 cal BCE $2 \sigma)$ is taken to be reliable, and it is assumed that the single primary burial at the base level of the second chamber is contemporary with those in the ante-chamber and first chamber, that would mean that the carved tusk and the rock crystal blade with ivory hilt and sheath would have been deposited at a later time. In fact, as it was noted above, these items are separated from the person buried at the bottom of the main chamber by $40 \mathrm{~cm}$ of infill.

Nevertheless, due to the errors in the other dated samples, it is difficult to see date Erl17299 as entirely reliable. Therefore, for the time being, the internal chronology of structure 10042-10049 must remain a matter of speculation.

Rather apart from the issue of chronology, the technical skill involved in the making of this collection of objects is most certainly outstanding. All the pieces studied here come from elephant tusks, which were cut and carved by very skilful artisans who gave the end products an excellent finish. Either metal saws or long, flint knives must have been used to cut the thick, tough tusks. Both tools are well documented for the period at Valencina - see for example the metal saw found in the ivory workshop described for the IES sector (Vargas Jiménez et al., 2012; Nocete Calvo et al., 2013). Once a basic pre-form was obtained for the final piece, the outer shape was carved. The composite design was drawn onto the almost smooth surface, with the outlines traced in natural pigments, a stick of coal, perhaps, used as a pencil or charcoal. Once the drawing was completed, each part of the decoration was carved. Tools used for this work could be of stone (flint knives, engraving chisels or scrapers), metal (saws, awls, chisels or scrapers) or made from other materials, such as shell or teeth. The surfaces of several pieces studies display some soft, shiny areas and may have been polished previously. 
The sophistication of the work in these objects suggests that there were highly skilled local craft-persons specialising in ivory work. It is not easy to establish whether this was strictly 'technical' specialisation (which is to say that they were people with technical skills only available to a small group and to which others had no access), or also 'socio-economic' specialisation, in the sense that they were full-time craftsmen, exempt from taking part in subsistence tasks, as suggested by Nocete Calvo et al., 2013.

The second remarkable feature of this collection of objects is the proven foreign provenance of the raw materials themselves (Table 2). Grave 10042-10049 is the only one in southern Iberia currently known to contain pieces in both African and Asian ivory. Other ivory objects from Valencina de la Concepcion show great diversity in the origins of raw materials:

- The two objects analysed so far from the great megalithic monument of Montelirio are made in ivory from African savannah elephant.

- The five fragments analysed to date from the IES sector workshop are from Asian elephant.

- The 12 pieces analysed from the great megalithic monument of Matarrubilla are $50 \%$ from the Elephas antiquus and $50 \%$ Asian ivory.

- One piece in tomb 5 from the Señorío de Guzmán sector is from Elephas antiquus.

Analytical data from other southern Iberian sites also show that ivory from several provenances was used throughout the region in the Copper Age (Table 4). The two pieces analysed from Cueva Antoniana (Gilena, Seville) (Rivero Galán, 1988: 68-70; Cruz-Auñón Briones et al., 1991) are from savannah elephant, while of the other two pieces from tomb 5 at Los Algarbes (Tarifa, Cadiz), one was Asian ivory and the other from Elephas antiquus. Another five pieces have been analysed from Los Millares (Santa Fe de Mondújar, Almería): of them, four are from Asian elephants and one from Elephas antiquus (Schuhmacher et al., 2009; Cardoso and Schuhmacher, 2012). In addition, The 49 pieces studied from other regions, such as Portuguese Estremadura, Alentejo and Spanish Extremadura include African elephant (63.3\%), Elephas antiquus $(2.0 \%)$ and sperm whale $(34.7 \%)^{5}$, but not Asian elephant. More recently, foreign ivory has started to be identified in Copper Age sites in central Spain, such as Camino de Yeseras (San Fernando de Henares, Madrid) and probably, Humanejos (Parla, Madrid) (Ríos Mendoza and Liesau Von Lettow, 2011: 365-67 figs. 4. 5; Liesau Von Lettow et al., 2011).

It is beyond dispute, therefore, that Valencina occupied an exceptional place in the ivory trade in Western Europe in the 3rd millennium BCE, because it was receiving ivory from both African and Asian elephants. The complete unworked tusk from grave

\footnotetext{
${ }^{5}$ We include here six items from Sobreira de Cima (Alentejo), because we understand that these belong to the end of the $4^{\text {th }}$ millennium BC and form a Late Neolithic or Early Chalcolithic deposit (Valera et al., 2008).
} 
10042-10049 and the material record from the IES sector workshop prove that at least some part of the raw material arrived at Valencina in the rough and was worked, transformed and used there, and very likely sent out to other southern Iberian regions. Hypotethically, this can be explained by the fact that Valencina de la Concepcion was part of two different trading networks (Figure 20). One operated on the Atlantic side, and through it African ivory was transported from the Atlantic coast of Morocco to the estuaries of the Tagus and Guadalquivir rivers. Through a second, Mediterranean route, Asian ivory reached southeast Spain and the Guadalquivir estuary (Schuhmacher and Banerjee 2012).

In this sense structure 10042-10049, provides additional fresh data demonstrating the participation of Valencina de la Concepción in supra-regional (and even supra-lberian) trade networks of luxury commodities (Figure 21). Apart from the ivory objects, this includes, one amber object of Sicilian origin (Murillo-Barroso and García Sanjuán, 2012), cinnabar pigments from central Spain (Rogerio-Candelera et al., 2013), flint probably imported from the Baetic mountain range and a north-African ostrich egg. Other foreign materials recently identified in Valencina include variscite beads from northern Spain. Altogether, this set of evidence fully confirms earlier suggestions about the scope of the supra-regional exchange of commodities between Northern Africa and Iberia as early as the $3^{\text {rd }}$ millennium BC (Harrison and Gilman, 1977), while at the same time throws serious doubts about the usefulness (or meaning) of the notion of "pre-colonisation" used in the study of the Phoenician colonisation of the Early Iron Age: as it turns out, there were solid trading contacts between the eastern and western shores of the Mediterranean as early as the beginning of the $3^{\text {rd }}$ millennium BC long before Mycenean and Phoenician goods started to make their way into Iberia.

Finally, the ideological and social dimension of these ivory objects must be noted. In addition to the exoticism of the raw material, the sophistication of the techniques applied and the sheer beauty of the finished objects leave little room to doubt that they were used and valued as luxury items in the grave goods of people belonging to the elites of the Copper Age communities living across the lower Guadalquivir valley.

In this respect, grave 10042-10049 is exceptional for the amount of ivory found in it, the quality and sophistication of the items (probably unique in Iberia), and for their associations with other artefacts (e.g. association of the hilt with the rock crystal dagger blade, or the carved vessel with cinnabar pigment). Grave 10042-10049 as a whole contains a quantity of luxury objects that, in Valencina, is perhaps only surpassed by the great megalithic monument of Montelirio, which is a mere $100 \mathrm{~m}$ away. In this respect, it is equally notable that there was a single body buried at the base level of the main chamber, along with grave goods that were clearly personalised, a relatively rare event in the Copper Age in which, as it is well known, the sheer 'collectiveness' of the burial practices makes it impossible to relate grave goods to specific individuals. The person buried at the base level of the main chamber of structure 10042-10049 received an exceptionally sumptuous grave set that included special objects, such as a flint dagger with amber pommel, a carved ivory vessel and a complete elephant tusk. The ambiguity of the carbon dating obtained makes it 
impossible to be sure whether the equally exceptional pieces in the upper level of the main chamber in grave 10042-10049 (most particularly, for example, the rock crystal dagger with ivory hilt) were part of the grave goods laid for the same person.

However, generally, the connection between this person with the large amount of ivory and other objects and exotic materials is important as they may demonstrate his high social standing and power - at least within the sphere of funerary ideology. With the data available it is legitimate to theorise that this person was a craftsman, middleman or merchant connected to the ivory trade, from which he might have obtained his personal wealth and his social status. In this respect, there are at least two highly interesting details. The first is the fact that the unworked tusk was already cut into three segments, as though ready for carving. The second is the almost complete absence of metal objects in grave 10042-10049 (only one very small copper item of indeterminate shape) - the scarcity of metal items can be extended to the whole of sector PP4-Montelirio. The power and prestige of the social elite in Valencina in the Copper Age, it seems, were linked to possessing and displaying exotic paraphernalia and definitely not to metal objects. This suggests that the importance and ideological significance of copper metallurgy in the Copper Age must be put into perspective, something that has implications when assessing the scale of metallurgical production, as we have claimed in previous work (Costa Caramé et al., 2010; Costa Caramé y García Sanjuán, 2010). Together, therefore, the evidence obtained from grave 10042-10049 and presented in this paper throws new light onto a series of controversial aspects in the study of social complexity in Iberian Copper Age, including craft specialisation, long-distance contacts and the fundaments and nature of social organisation.

\section{Note}

This paper has been written within the R\&D project "A Comparative Analysis of Socioeconomic Dynamics in Late Prehistory in the Central south of the Iberian Peninsula $\left(4^{\text {th }}-2^{\text {nd }}\right.$ millennia $\left.B C\right)$ : The South-west" (HAR2009-14360-C03-03), funded by the Spanish Ministry of Science and Innovation. We must also acknowledge the financial support of the General Directorate of Cultural Properties of the Andalusian Regional Government for the restoration and study of the ivory objects presented in this paper. The analysis of the ivory objects was financed by the German Science Foundation (DFG, Bonn) as part of the two research projects SCHU 1539/2-2 and 3-1 carried out by the German Archaeological Institute, Madrid. We would also like to thank the Seville Museum of Archaeology staff for their support and advice while doing this research.

\section{5.- Bibliography}

Almagro Gorbea, M.J. 1973. Los Ídolos del Bronce I Hispano. Bibliotheca Praehistorica Hispana, vol. XII. Madrid.

Aubet Semmler, M.E. 1979. Los Marfiles Fenicios del Bajo Guadalquivir (I). La Cruz del Negro. Studia Archeologica 52. Valladolid. Universidad de Valladolid

Aubet Semmler, M.E. 1980. Los Marfiles Fenicios del Bajo Guadalquivir (II). Acebuchal y Alcantarilla. Studia Archeologica 63. Valladolid. Universidad de Valladolid 
Aubet Semmler, M.E. 1982. Marfiles fenicios del Bajo Guadalquivir III (Bencarrón, Santa Lucía, Setefilla). Pyrenae 17-18 : 231-279.

Bailloud, G. \& Mieg de Boofzheim, P. 1964. La nécropole néolithique d’El-Kiffen. Libyca 12: $95-171$.

Banerjee, A. \& Huth, J. 2012. Investigation of archaeological ivory. In: A. Banerjee, J.A. Lopez Padilla \& TH.X. Schuhmacher, eds. Elfenbeinstudien. 1, Marfil y elefantes en la Península Ibérica y el Mediterráneo occidental Actas del coloquio internacional en Alicante el 26 y 27 de noviembre 2008. Deutsches Archäologisches Institut : Diputación Provincial de Alicante, pp. 15-28.

Banerjee, A., Dindorf, W., Mikdad, A., Reischmann, TH. \& Schuhmacher, TH.X. 2011a. Die Elfenbeinfunde aus Kehf-el-Baroud (Ziaïda, Ben Slimane, Marokko) und die Frage des Nordafrikanischen Elefanten. Madrider Mitteilungen 52: 113-138.

Banerjee, A., Huth, J., Dindorf \& W. 2011b. Untersuchungen von archäologischem Elfenbein. In: A. Banerjee \& CH. Eckmann, eds. Elfenbein und Archäologie. INCENTIVS Tagungsbeiträge 2004-2007. RGZM Tagungen 7. Mainz: Römisch-Germanisches Zentralmuseum Mainz, pp. 1-18.

Barciela González, V. 2012. Tecnología del marfil en la Edad del Bronce de la Meseta Sur (España). In: A. Banerjee, J.A. López Padilla \& TH.X. Schuhmacher, eds. Marfil y Elefantes en la Península Ibérica y el Mediterráneo. Actas del Coloquio Internacional en Alicante (26-27 de Noviembre de 2008). Mainz: Deutsches Archäologisches Institut/Museo Arqueológico de Alicante, pp. 199-214.

Bokbot, Y. 2005. La civilización del vaso Campaniforme en Marruecos y la cuestión del sustrato Calcolítico pre-campaniforme. In: M. Rojo-Guerra, R. Garrido-Pena \& I. GarcíaMartínez de Lagrán, eds. El Campaniforme en la Península Ibérica y su Contexto Europeo. Valladolid: Universidad de Valladolid, pp. 137-173.

Camps, G. 1960. Les traces d'un Age du Bronze en Afrique du Nord. Revue Africaine $104: 31-55$.

Cardoso, J.L. \& Schuhmacher, TH.X. 2012. Marfiles calcolíticos en Portugal. Estado de la cuestión. In: A. Banerjee, J.A. López Padilla \& TH.X. Schuhmacher, eds. Marfil y Elefantes en la Península Ibérica y el Mediterráneo. Actas del Coloquio Internacional en Alicante (26-27 de Noviembre de 2008). Mainz: Deutsches Archäologisches Institut and Museo Arqueológico de Alicante, pp. 95-110.

Cardoso, J.L. 1995. Ossos de cetáceo usados no Calcolítico da Estremadura. Estudos Arqueológicos de Oeiras 5: 193-198.

Cardoso, J.L. 2003. O uso do marfim, no territorio portugués durante o Calcolítico: a propósito de um alfinete recolhido no povoado pre-histórico de Leceia (Oeiras). Estudos Arqueologicos de Oeiras 11: 85-96. 
Collantes de Terán, F. 1969. El dolmen de Matarrubilla. V Symposium Internacional de Prehistoria Peninsular (Jerez de la Frontera 1969): 47-61.

Costa Caramé, M.E., Díaz-Zorita Bonilla, M., García Sanjuán, L. \& Wheatley, D.W. 2010. The Copper Age settlement of Valencina de la Concepción (Seville, Spain): demography, metallurgy and spatial organization. Trabajos de Prehistoria 67(1): 87118.

Cruz-Aunón Briones, R., Moreno Alonso, E. \& Cáceres Misa, P. 1991. Campaña de 1989 en el yacimiento del Negrón (Gilena, Sevilla). Anuario Arqueológico de Andalucía/1989: 315-320.

Daugas, J.P. 2002. Le néolithique du Maroc. Pour un modèle d'evolution chronologique et culturelle. Bulletin d'Archéologie Marocaine 19: 135-175.

Díaz-Guardamino Uribe, M. 2010. Las estelas decoradas de la Península Ibérica. Madrid: Universidad Complutense de Madrid.

Estacio da Veiga, S.P. 1886-1891. Palaeoethnologia. Antiguidades Monumentães do Algarve 1-4. Lisboa.

Fernandez Flores, A. \& Aycart Luengo, V. 2012. Montelirio. Un sepulcro clave para la comprensión de los grandes monumentos funerarios de Valencina de la Concepción Castilleja de Guzmán. In: L. García Sanjuán, J.M. Vargas Jiménez, V. Hurtado Pérez, T. Ruiz Moreno \& R. Cruz-Auñón Briones, eds. El Asentamiento Prehistórico de Valencina de la Concepción (Sevilla): Investigación y Tutela en el 150 Aniversario del Descubrimiento de La Pastora. Sevilla: Universidad de Sevilla, pp. 223-260.

Fonseca Ferrandis, R. 1988. Botones de marfil de perforación en V del Cerro de la Encantada (Granátula de Calatrava, Ciudad Real). Actas del I Congreso de Historia de Castilla-La Mancha. Tomo 3: 161-168.

García Sanjuán, L. \& Murillo-Barroso, M. 2013. Social complexity in Copper Age Southern Iberia (c. 3200-2200 cal BC): reviewing the 'state' hypothesis at Valencina de la Concepción (Seville, Spain). In: M. Cruz Berrocal, L. García Sanjuán \& A. Gilman, eds. The Prehistory of Iberia: Debating Early Social Stratification and the State. New York: Routledge, pp. 119-140.

Gonçalves, V.S. et al. 2005. Cascais Há 5000 anos. Cascais: Câmara Municipal de Cascais.

Götze, A. 1925. Elfenbein, Europa. In: M. Ebert, ed. Reallexikon der Vorgeschichte 3. Berlin, pp. 87. 
Harrison, R. J. \& Gilman, A. 1977. Trade in the second and third millennia B.C. between the Maghreb and Iberia. In: V. Markotic, ed. Ancient Europe and the Mediterranean: Studies In Honour of Hugh Hencken. Warminster: Aris and Phillips, pp. 90-104.

Inacio, N., Nocete Calvo, F., Nieto Liñán, J. M., Rodríguez Bayona, M. \& Abril López, D. 2011. From raw materials to utilisation: Ceramics associated with the metallurgical activity at Valencina de la Concepcion (Seville, Spain): technological choices and social implication. In: S. Scarcella, ed. Archaeological Ceramics: A Review of Current Research. BAR S2193. Oxford: Archaeopress, 73-79.

Jodin, A. 1957. Les problèmes de la civilisation du vase campaniforme au Maroc. Hespéris 44 : 353-360.

Juárez Martín, J. M. ed. 2010. El Enterramiento en Cueva Artificial de La Molina (Lora de Estepa, Sevilla). Sevilla: Junta de Andalucía.

Lago, M., Duarte, C., Valera, A., Albergaria, J., Almeida, F. \& Carvalho, A.F. 1998. Povoado dos Perdigões (Reguengos de Monsaraz): dados preliminares dos trabalhos arqueológicos realizados em 1997. Revista Portuguesa de Arqueologia 1: 45-152.

Leisner, G. \& Leisner, V. 1943. Die Megalithgräber der Iberischen Halbinsel. Der Süden (Römisch-Germanische Forschungen 17). Berlin: Walter de Gruyter.

Liesau Von Lettow, C. \& Moreno, E. 2012. Marfiles campaniformes de Camino de las Yeseras (San Fernando de Henares, Madrid). In: A. Banerjee, J.A. López Padilla \& TH.X. Schuhmacher, eds. Marfil y Elefantes en la Península Ibérica y el Mediterráneo. Actas del Coloquio Internacional en Alicante (26-27 de Noviembre de 2008). Mainz: Deutsches Archäologisches Institut/Museo Arqueológico de Alicante, pp. 83-94.

Liesau Von Lettow, C. \& Schuhmacher, TH.X. 2012. Un taller de marfil del Bronce argárico en el yacimiento de Fuente Álamo (Cuevas del Almanzora, Almería). In: A. Banerjee, J.A. López Padilla \& TH.X. Schuhmacher, eds. Marfil y Elefantes en la Península Ibérica y el Mediterráneo. Actas del Coloquio Internacional en Alicante (26-27 de Noviembre de 2008). Mainz: Deutsches Archäologisches Institut/Museo Arqueológico de Alicante, pp. 121-138.

Liesau Von Lettow, C., Banerjee, A. \& Schwarz, J.O. 2011. Camino de Las Yeseras' ivory collection: advances in analysis technology used in identifying raw material. In: $\mathrm{C}$. Blasco Bosqued, C. Liesau \& P. Ríos Mendoza, eds. Yacimientos Calcolíticos con Campaniforme de la Región de Madrid: Nuevos Estudios. Patrimonio Arqueológico de Madrid 6. Madrid: Universidad Autónoma de Madrid, pp. 381-386.

López Padilla, J.A. 2012. Dinámica de la producción y consumo de marfil en el sudeste y área centro-meridional del levante peninsular entre ca. 2200 y ca. 1200 BC. In: A. Banerjee, J.A. López Padilla \& TH.X. Schuhmacher, eds. Marfil y Elefantes en la Península Ibérica y el Mediterráneo. Actas del Coloquio Internacional en Alicante (26-27 
de Noviembre de 2008). Mainz: Deutsches Archäologisches Institut and Museo Arqueológico de Alicante, pp.139-156.

López Padilla, J.A. 2006. Marfil, oro, botones y adornos en el área oriental del país de El Argar. MARQ. Arqueología y Museos 1: 25-48.

López Padilla, J.A. 2009. El irresistible poder de la ostentación: la artesanía del marfil en Lorca en la época de El Argar. Alberca 7: 7-24.

Luciañez Triviño, M. 2012. Estudio arqueológico y tratamiento de ConservaciónRestauración de objetos de marfil procedentes del Yacimiento de la Edad del Cobre de Valencina de la Concepción-Castilleja de Guzmán (Sevilla). Sevilla: University of Sevilla. Unpublished Master Dissertation.

Maicas Ramos, R. 2007. Industria Ósea y Funcionalidad: Neolítico y Calcolítico en la Cuenca de Vera (Almería). Madrid: Consejo Superior de Investigaciones Científicas, CSIC.

Mora Molina, C., García Sanjuán, L., Peinado Cucarella, J. \& Wheatley, D. 2012. Las estructuras de la Edad del Cobre del Sector PP4-Montelirio del sitio arqueológico de Valencina de la Concepción-Castilleja de Guzmán (Sevilla). In: L. García Sanjuán, J.M. Vargas Jiménez, V. Hurtado Pérez, T. Ruiz Moreno \& R. Cruz-Auñón Briones, eds. El Asentamiento Prehistórico de Valencina de la Concepción (Sevilla): Investigación y Tutela en el 150 Aniversario del Descubrimiento de La Pastora. Sevilla: Universidad de Sevilla, pp. 261-280.

Murillo-Barroso, M. \& García Sanjuán, L. 2012. El pomo de ámbar de la estructura 10.042-10.049 del sector PP4-Montelirio del asentamiento de Valencina de la Concepción (Sevilla). In: L. García Sanjuán, J.M. Vargas Jiménez, V. Hurtado Pérez, T. Ruiz Moreno \& R. Cruz-Auñón Briones, eds. El Asentamiento Prehistórico de Valencina de la Concepción (Sevilla): Investigación y Tutela en el 150 Aniversario del Descubrimiento de La Pastora. Sevilla: Universidad de Sevilla, pp. 511-519.

Nocete Calvo, F., Queipo de Llano, G., Sáez, R., Nieto Liñán, J.M., Inácio, N., Rodríguez Bayona, M.R., Páramo, A., Vargas Jiménez, J.M., Cruz-Auñón Briones, R., Gil-Ibarguchi, J.I. \& Santos, J.F. 2008. The smelting quarter of Valencina de la Concepción (Seville, Spain): the specialised copper industry in a political centre of the Guadalquivir valley during the third millennium BC (2750-2500 BC). Journal of Archaeological Science 35: 717-732.

Nocete Calvo, F., Vargas Jiménez, M.A., Schuhmacher, TH. X., Banerjee, A. \& Dindorf, W. 2013. The ivory workshop of Valencia de la Concepción (Seville, Spain) and the identification of ivory from Asian elephant on the Iberian Peninsula in the first half of the 3rd millennium BC. Journal of Archaeological Science: pp 
Pascual Benito, J.L. 1995. Origen y significado del marfil durante el Horizonte Campaniforme y los inicios de la Edad del Bronce en el País Valenciano. Saguntum 29: 19-31.

Pascual Benito, J.L. 2012. El taller de marfil del Bronce Pleno de Mola d'Agres (Alicante). In: A. Banerjee, J.A. López Padilla \& TH.X. Schuhmacher, eds. Marfil y Elefantes en la Península Ibérica y el Mediterráneo. Actas del Coloquio Internacional en Alicante (26-27 de Noviembre de 2008). Mainz: Deutsches Archäologisches Institut and Museo Arqueológico de Alicante, pp. 173-198.

Poyato Holgado, C. \& Hernando Grande, A. 1988. Relaciones entre la Península Ibérica y el Norte de África: marfil y campaniforme. In: E. Ripio Perelló, ed. Actas del Congreso Internacional El Estrecho de Gibraltar (Ceuta 1987), Volumen 1, pp. 317-329.

Rivero Galán, E. 1988. Análisis de las Cuevas Artificiales en Andalucía y Portugal. Sevilla: Universidad de Sevilla.

Robles Carrasco, S. \& Díaz-Zorita Bonilla, M. 2012. Análisis bioarqueológico de tres contextos-estructuras funerarias del sector PP4-Montelirio del yacimiento de Valencina de la Concepción-Castilleja de Guzmán (Sevilla). In: L. García Sanjuán, J.M. Vargas Jiménez, V. Hurtado Pérez, T. Ruiz Moreno \& R. Cruz-Auñón Briones, eds. El Asentamiento Prehistórico de Valencina de la Concepción (Sevilla): Investigación y Tutela en el 150 Aniversario del Descubrimiento de La Pastora. Sevilla: Universidad de Sevilla, pp. 369-386.

Robles Carrasco, S. 2011. Análisis bioarqueológico de tres contextos-estructuras funerarias del sector PP4-Montelirio, del yacimiento de Valencina de la ConcepciónCastilleja de Guzmán (Sevilla). Madrid: UAM-UCM-UAH. Unpublished Master Dissertation.

Rogerio-Candelaria, M.A., Karen Herrera, L., Millar, A.Z, García Sanjuán, L., Mora Molina, C., Wheatley, D.W, Justo, A. \& Saiz-Jimenez, C. 2013. Red pigments used in burial practices at the Copper Age site of Valencina de la Concepción (Sevilla, Spain): characterisation and social dimension. Journal of Archaeological Science 40: 279-290.

Schuhmacher, TH.X. \& Banerjee, A. 2011. Pottwalelfenbein im chalkolithischen Portugal. Restaurierung und Archäologie 4: 107-119.

Schuhmacher, TH.X. \& Banerjee, A. 2012. Procedencia e intercambio de marfil en el Calcolítico de la península ibérica. In: M. Borrel, F. Borrell, J. Bosch, X. Clop \& M. Molist, eds. Redes en el Neolítico. Circulación e Intercambio de Materias, Productos e Ideas en el Mediterráneo Occidental (VII-III milenio a. C.) (Gavá, Bellaterra, 2-4 de Febrero de 2011). Gavá : Ajuntament de Gavá, pp. 289-298.

Schuhmacher, TH.X. \& Cardoso, J.L. 2007. Ivory objects from the chalcolithic fortification of Leceia (Oeiras). Estudos Arqueologicos de Oeiras 15: 95-118. 
Schuhmacher, TH.X. 2012. El marfil en España desde el Calcolítico al Bronce Antiguo. Resultados de un Proyecto de Investigación Interdisciplinar. In: A. Banerjee, J.A. López Padilla \& TH.X. Schuhmacher, eds. Marfil y Elefantes en la Península Ibérica y el Mediterráneo. Actas del Coloquio Internacional en Alicante (26-27 de Noviembre de 2008). Mainz: Deutsches Archäologisches Institut and Museo Arqueológico de Alicante, pp. 45-68.

Schuhmacher, TH.X. in press. Die Elfenbeinobjekte des Chalkolithikums und der Frühen Bronzezeit auf der Iberischen Halbinsel. Interdisziplinäre Studien zu Herkunft, Austausch, Verarbeitung und sozialer Bedeutung von Elfenbein. Iberia Archaeologica 16,2 .

Schuhmacher, TH.X., Banerjee, A., Dindorf, W. Sastri, C. \& Sauvage, T. 2013. The use of Sperm whale ivory in Chalcolithic Portugal. Trabajos de Prehistoria: pp.

Schuhmacher, TH.X., Banerjee, A., Dindorf, W., Nocete Calvo, F. \& Vargas Jiménez, J.M. 2012. Los marfiles del yacimiento de Valencina en el contexto del Calcolítico del Suroeste peninsular. In: L. García Sanjuán, J.M. Vargas Jiménez, V. Hurtado Pérez, T. Ruiz Moreno \& R. Cruz-Auñón Briones, eds. El Asentamiento Prehistórico de Valencina de la Concepción (Sevilla): Investigación y Tutela en el 150 Aniversario del Descubrimiento de La Pastora. Sevilla: Universidad de Sevilla, pp. 495-510.

Schuhmacher, TH.X., Cardoso, J.L. \& Banerjee, A. 2009. Sourcing African ivory in Chalcolithic Portugal. Antiquity 83: 983-997.

Serra-Ràfols, J. De C. 1925. cf. Elfenbein, Pyrenäenhalbinsel. In: M. Ebert. ed. Reallexikon der Vorgeschichte 3, Berlin: Walter de Gruyter, pp. 87-8.

Siret, L. 1913. Questions de Chronologie et d'Éthnographie Iberiques. Paris: Paul Geuthner.

Spindler, K. 1981. Cova da Moura. Die Besiedlung des Atlantischen Küstengebietes Portugals vom Neolithikum bis an das Ende der Bronzezeit. Madrider Beiträge 7. Mainz.

Valera, A.C. 2009. Marfim no recinto calcolítico dos Perdigões: lúnulas, fragmentação e ontologia dos artefactos. Apontamentos de Arqueologia e Património 5: 25-36.

Valera, A.C., Monge Soares, A. \& Coelho, M. 2008. Primeiras datas de radiocarbono para a necrópole de hipogeus da Sobreira de Cima (Vidigueira, Beja). Apontamentos de Arqueologia e Património 2: 27-30.

Valera, A., Lago, M., Duarte, C. \& Shaw Evangelista, L. 2000. Ambiente funerários no complexo Arqueológico dos Perdigões. Era Arqueología 2: 84-105.

Vargas Jiménez, J.M., Nocete Calvo, F. \& Schuhmacher TH.X. 2012. Contextos de producción de objetos de marfil en Valencina de la Concepción (Sevilla). In: A. Banerjee, J.A. López Padilla \& TH.X. Schuhmacher, eds. Marfil y Elefantes en la 
Península Ibérica y el Mediterráneo. Actas del Coloquio Internacional en Alicante (26-27 de Noviembre de 2008). Mainz: Deutsches Archäologisches Institut and Museo Arqueológico de Alicante, pp. 69-82.

Wheatley, D., Strutt, C., García Sanjuán, L., Peinado Cucarella, J. \& Mora Molina. 2012. New evidence on the spatial organisation of the Valencina de la Concepción Copper Age settlement: the geophysics between La Pastora and Montelirio. Trabajos de Prehistoria 69(1): 65-79. 


\section{List of Tables}

Table 1. Result of isotopic analysis: $\delta \mathrm{C}$ and $\delta \mathrm{N}$ values

Table 2. Analyzed samples from Valencina de la Concepción

Table 3. C14 dates obtained from ivory objects

Table 4. Percentages of raw material in different regions of Iberia.

\section{List of Figures}

Figure 01. Location of Valencina in the Iberian peninsula.

Figure 02. Overview of megalithic tomb 10042-10049. Photograph: José Peinado Cucarella.

Figure 03: Structure 10042-10049, detail of main chamber, lower depositional level (earlier use). Photograph: José Peinado Cucarella.

Figure 04. Structure 10042-10049: detail of main chamber, upper depositional level (later use). Photograph: José Peinado Cucarella.

Figure 05: Unworked elephant tusk. Photograph: Miguel Ángel Blanco de la Rubia.

Figure 06. Carved vessel, inside view (left); b: Carved vessel, outside view (right).

Photograph: Miguel Ángel Blanco de la Rubia.

Figure 07. Carved vessel. Drawing by Elisabet Conlin.

Figure 08. Carved elephant tusk. Photograph: Miguel Ángel Blanco de la Rubia.

Figure 09. Details of the decoration motifs of carved elephant tusk. Remains of cinnabar pigment can be seen on the left hand side. Photograph: Miguel Ángel Blanco de la Rubia.

Figure 10. Carved elephant tusk. Drawing by Elisabet Conlin.

Figure 11. a) Dagger hilt (anverse) (left); b: Dagger hilt (reverse) (righ). Photograph: Miguel Ángel Blanco de la Rubia.

Figure 12. Dagger hilt. Drawing by Elisabet Conlin.

Figure 13. Dagger hilt with rock crystal blade. Photograph: Miguel Ángel Blanco de la Rubia.

Figure 14. a) Carved plaque or sheath (anverse); b) Carved plaque or sheath (reverse). Photograph: Miguel Ángel Blanco de la Rubia.

Figure 15. Carved plaque or sheath. Drawing by Elisabet Conlin.

Figure 16. Dagger hilt with rock crystal blade and sheath. Photograph: Miguel Ángel Blanco de la Rubia.

Figure 17. Idealised reconstruction of the suspension system for the dagger. Drawing: Miriam Luciañez Triviño.

Figure 18. FTIR spectrum (Absorbance) from 1500 and $500 \mathrm{~cm}^{-1}$ of sample Elf 766 . This spectrum, as well as the FTIR spectra of other samples, match with the Standard FTIR spectrum (FTIR database) of Elephas maximus (Asian elephant).

Figure 19. FTIR Spectrum (Absorbance) in the region 1500 and $500 \mathrm{~cm}^{-1}$ of sample Elf 727. This spectrum, as well as the FTIR spectra of other samples, match with the standard FTIR spectrum (FTIR-database) of Loxodonta africana (African savannah elephant). 
Figure 20. Distribution map of ivory objects during the early Chalcolithic (first half of the $3^{\text {rd }}$ millennium BC): 1 Cova da Moura; 2 Zambujal; 3 Leceia; 4 Palmela; 5 Anta da Herdade da Capela; 6 La Pijotilla; 7 Nora; 8 Valencina de la Concepción; 9 Cueva Antoniana (Gilena); 10 Los Millares. Ivory of African Savannah Elephant; Ivory of Asian Elephant. Design: Thomas Schuhmacher.

$1-2 ; \quad 3-10 ; \quad 11-20 ; \quad 21-30 ; \quad 31-40 ; \quad 41-50 ; \quad>$ more than 50 ivory objects. Figure 21. Synthethic map showing the provenance of foreign objects found at Valencina de la Concepción. 


\begin{tabular}{|c|c|c|c|c|}
\hline Sample & $\% \mathrm{C}$ & $\% \mathrm{~N}$ & $\delta \mathrm{C} \%$ & $\delta \mathrm{N} \%$ \\
\hline Elf 723 & 10.06 & 2.32 & -19.36 & 17.13 \\
\hline Elf 724 & 5.49 & 1.62 & -18.15 & 16.94 \\
\hline Elf 725 & 7.65 & 1.97 & -19.13 & 17.47 \\
\hline Elf 726 & 5.39 & 2.14 & -19.30 & 17.87 \\
\hline Elf 766 & 7.61 & 1.43 & -20.80 & 13.25 \\
\hline Elf 767 & 4.30 & 0.29 & -21.99 & 11.29 \\
\hline Elf 768 & 7.71 & 1.42 & -21.10 & 14.01 \\
\hline Elf 769 & 7.88 & 1.57 & -20.16 & 11.74 \\
\hline Elf 1466 & 4.35 & 0.11 & -18.05 & NA \\
\hline Elf 1470 & 4.28 & 0.14 & -16.48 & NA \\
\hline Elf 1729 & 4.79 & 0.15 & -20.83 & NA \\
\hline Elf 1730 & 5.10 & 0.25 & -20.92 & NA \\
\hline Elf 1731 & 3.76 & 0.10 & -16.06 & NA \\
\hline
\end{tabular}

\begin{tabular}{|c|c|c|c|c|}
\hline Sector & Context & $\begin{array}{l}\text { Sample } \\
\text { Number }\end{array}$ & Object & Result \\
\hline PP4-Montelirio & Structure 10.042-10.049 & Elf 1466 & Cylindrical box & Elephas maximus \\
\hline PP4-Montelirio & Structure 10.042-10.049 & Elf 1470 & Dagger Sheat & Elephas maximus \\
\hline PP4-Montelirio & Structure 10.042-10.049 & Elf 1729 & Dagger handle & Elephas maximus \\
\hline PP4-Montelirio & Structure 10.042-10.049 & Elf 1730 & Plaque & Elephas maximus \\
\hline PP4-Montelirio & Structure 10.042-10.049 & Elf 1731 & Drinking-horn? & Elephas maximus \\
\hline PP4-Montelirio & Structure 10.042-10.049 & Elf 1064 & Tusk & Loxodonta a. africana \\
\hline Montelirio & (Megalithic Moument) & Elf 1727 & Comb & Loxodonta a. africana \\
\hline Montelirio & (Megalithic Moument) & Elf 1728 & Acorn-pendant? & Loxodonta a. africana \\
\hline IES & Pit 402 & Elf 766 & Production waste & Elephas maximus \\
\hline IES & Pit 402 & Elf 767 & Production waste & Elephas maximus \\
\hline IES & Pit 402 & Elf 768 & Production waste & Elephas maximus \\
\hline IES & Pit 402 & Elf 769 & Production waste & Elephas maximus \\
\hline IES & Pit 402 & Elf 770 & Production waste & Elephas maximus \\
\hline Matarrubilla & (Megalithic Moument) & Elf 151 & Rectangular pendant & Elephas maximus \\
\hline Matarrubilla & (Megalithic Moument) & Elf 154 & Tusk fragment & Elephas antiquus \\
\hline Matarrubilla & (Megalithic Moument) & Elf 448 & Quadrangular bead & Elephas antiquus \\
\hline Matarrubilla & (Megalithic Moument) & Elf 449 & Quadrangular bead & Elephas antiquus \\
\hline Matarrubilla & (Megalithic Moument) & Elf 153 & Multiple channel bead & Elephas antiquus \\
\hline Matarrubilla & (Megalithic Moument) & Elf 153 & Multiple channel bead & Elephas antiquus \\
\hline Matarrubilla & (Megalithic Moument) & Elf 450 & Multiple channel bead & Elephas maximus \\
\hline Matarrubilla & (Megalithic Moument) & Elf 450 & Multiple channel bead & Elephas maximus \\
\hline Matarrubilla & (Megalithic Moument) & Elf 450 & Multiple channel bead & Elephas maximus \\
\hline
\end{tabular}




\begin{tabular}{|c|c|c|c|c|}
\hline Matarrubilla & (Megalithic Moument) & Elf 452 & Multiple channel bead & Elephas maximus \\
\hline Matarrubilla & (Megalithic Moument) & Elf 157 & L-formed pendant & Elephas antiquus \\
\hline Matarrubilla & (Megalithic Moument) & Elf 444 & Raw material & Elephas maximus \\
\hline Señorío de Guzmán & Tomb 5 & Elf 102 & Disk of raw material & Elephas antiquus \\
\hline
\end{tabular}

\begin{tabular}{|c|c|c|c|}
\hline OBJECT & SIGNATURE & $\begin{array}{c}\text { DATE } \\
\text { BP }\end{array}$ & DATE BC $2 \sigma$ \\
\hline Vessel (UE-664-1) & Erl-17297 & $2299 \pm 68$ & $540-178$ cal BCE \\
\hline Sheath(UE 535) & Erl-17298 & $2439 \pm 58$ & 759-403 cal BCE \\
\hline Hilt (UE 535) & Erl-17299 & $3905 \pm 74$ & 2575-2197 cal BCE \\
\hline Decorated tusk (UE 535) & Erl-17300 & $1930 \pm 57$ & $43 \mathrm{cal} \mathrm{CE}-221 \mathrm{cal} \mathrm{CE}$ \\
\hline Unworked tusk & Erl-17588 & $2180 \pm 55$ & 384-92 cal BCE \\
\hline \multicolumn{4}{|c|}{ Table 3. C14 dates obtained from ivory objects } \\
\hline
\end{tabular}




\begin{tabular}{|c|c|c|c|c|c|c|}
\hline & & $\begin{array}{l}\text { Elephas } \\
\text { antiquus }\end{array}$ & $\begin{array}{l}\text { Elephas } \\
\text { maximus }\end{array}$ & $\begin{array}{l}\text { Loxodonta } \\
\text { a. africana }\end{array}$ & $\begin{array}{l}\text { Sperm- } \\
\text { whale }\end{array}$ & Total \\
\hline \multirow{3}{*}{$\begin{array}{l}\text { Early Copper Age } \\
\text { (aprox. } \\
3200 / 3000- \\
2500 \text { BC) }\end{array}$} & Guadalquivir & 0 & $10(66 \%)$ & $5(33 \%)$ & 0 & 15 \\
\hline & $\begin{array}{l}\text { Portugal, } \\
\text { Extremadura }\end{array}$ & $1(5,6 \%)$ & 0 & $15(83,3 \%)$ & $2(11,1 \%)$ & 18 \\
\hline & Southeast & $1(25 \%)$ & 4 (75\%) & 0 & 0 & 5 \\
\hline \multirow{4}{*}{$\begin{array}{l}\text { Late Copper/ } \\
\text { Early Bronze Age } \\
\text { (2500-1900 BC) }\end{array}$} & $\begin{array}{l}\text { Guadalquivir, } \\
\text { Cádiz }\end{array}$ & $8(53,3 \%)$ & $7(46,7 \%)$ & 0 & 0 & 15 \\
\hline & $\begin{array}{l}\text { Portugal, } \\
\text { Huelva }\end{array}$ & 0 & 0 & $17(53,1 \%)$ & $15(46,9 \%)$ & 32 \\
\hline & Inner Spain & 9 (90\%) & 0 & $1(10 \%)$ & 0 & 10 \\
\hline & Southeast & 0 & $2(25 \%)$ & $6(75 \%)$ & 0 & 8 \\
\hline Total & & 19 & 23 & 44 & 17 & 103 \\
\hline
\end{tabular}




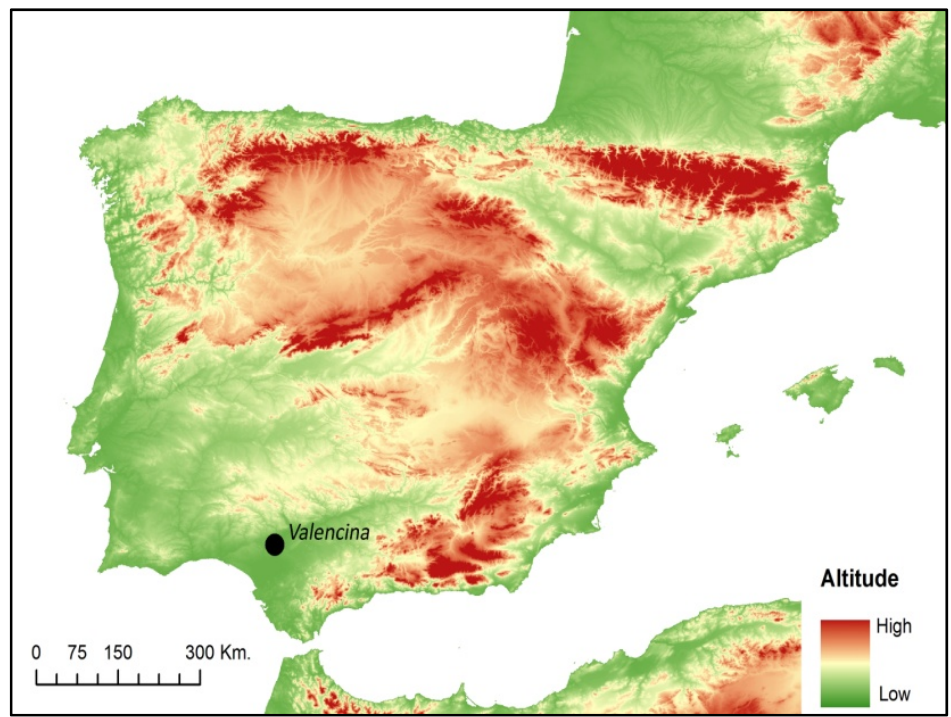

Figure 01: Location of Valencina in the Iberian peninsula.

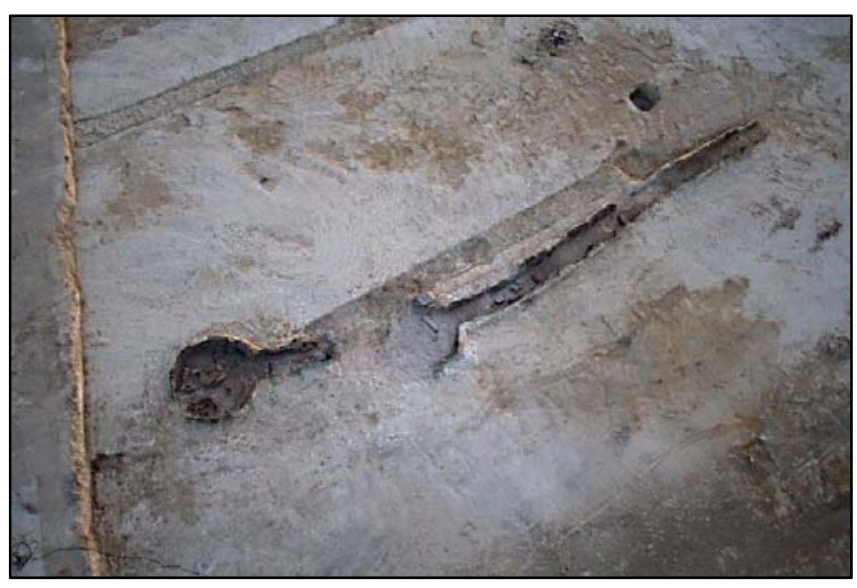

Figure 02: Overview of megalithic tomb 10042-10049. Photograph: José Peinado Cucarella.

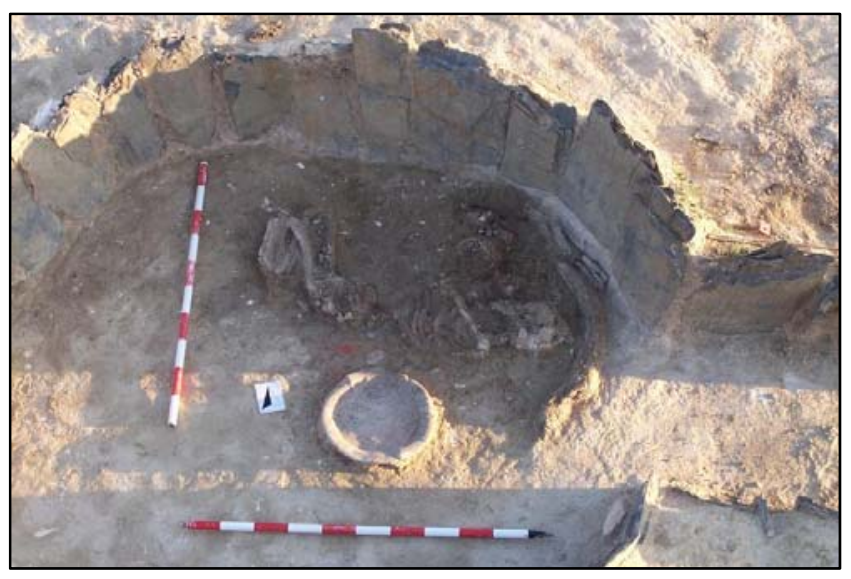

Figure 03: Structure 10042, detail of main chamber, lower depositional level (earlier use). Photograph: José Peinado Cucarella. 


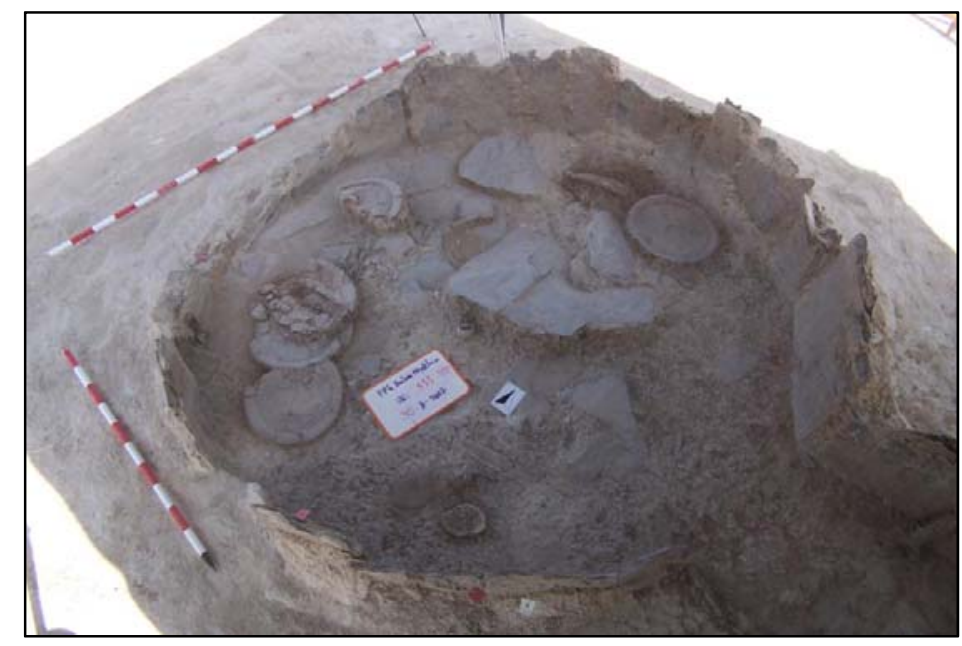

Figure 04: Structure 10042, detail of main chamber, upper depositional level (later use). Photograph: José Peinado Cucarella.

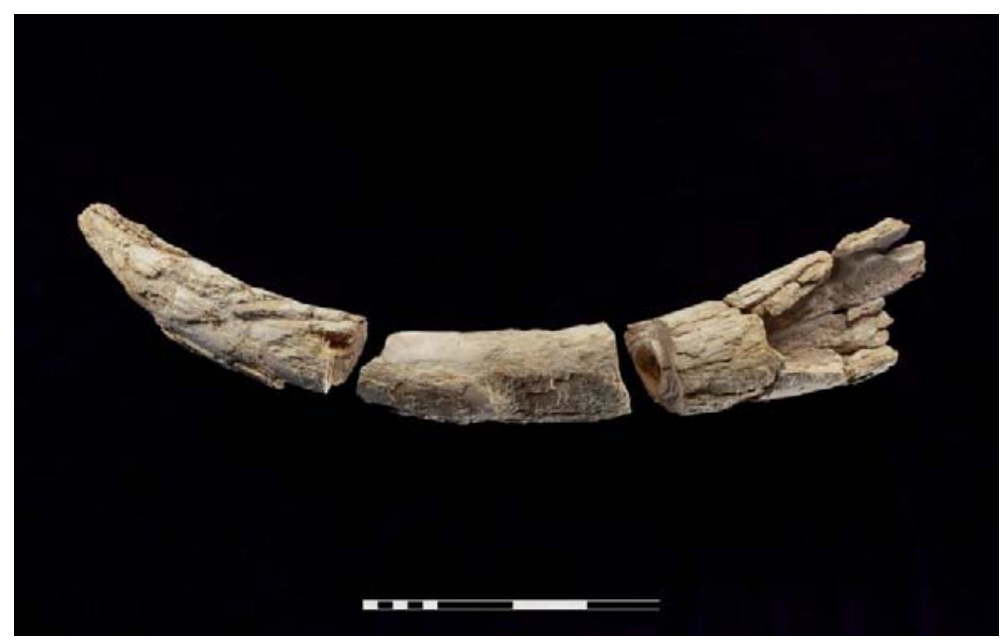

Figure 05: Unworked elephant tusk. Photograph: Miguel Ángel Blanco de la Rubia.

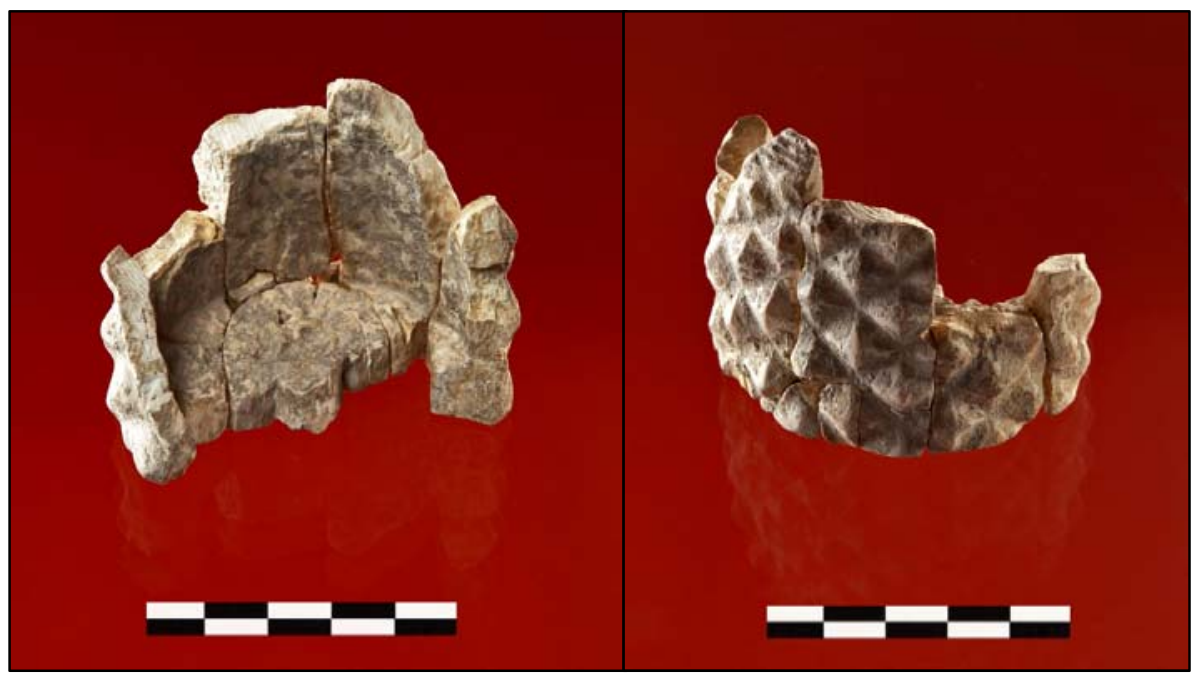

Figure 06: Carved vessel, inside (left) and outside (right) views. Photograph: Miguel Ángel Blanco de la Rubia. 


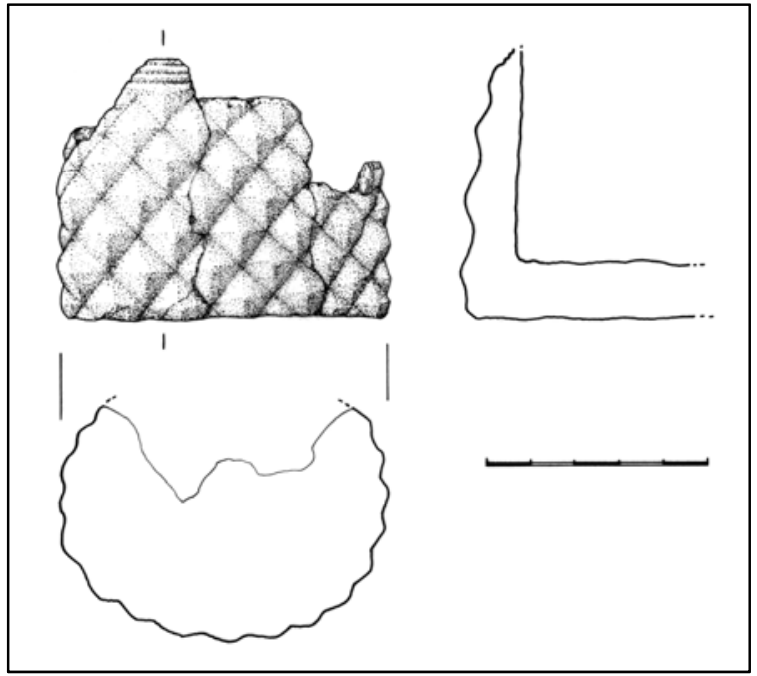

Figure 07: Carved vessel. Drawing by Elisabet Conlin.

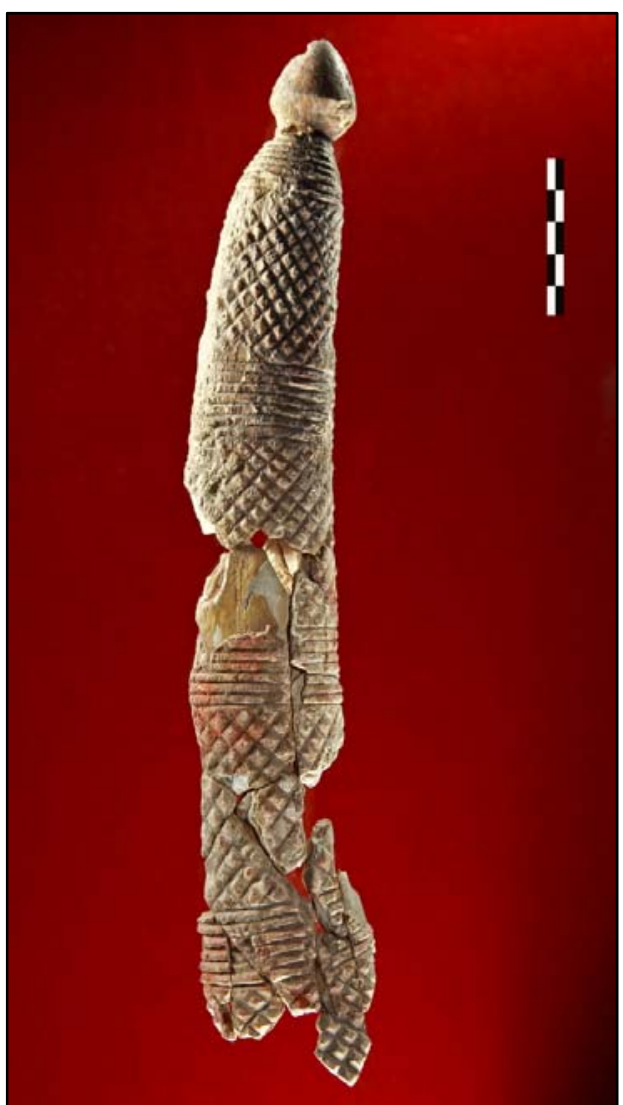

Figure 08: Carved elephant tusk. Photograph: Miguel Ángel Blanco de la Rubia. 


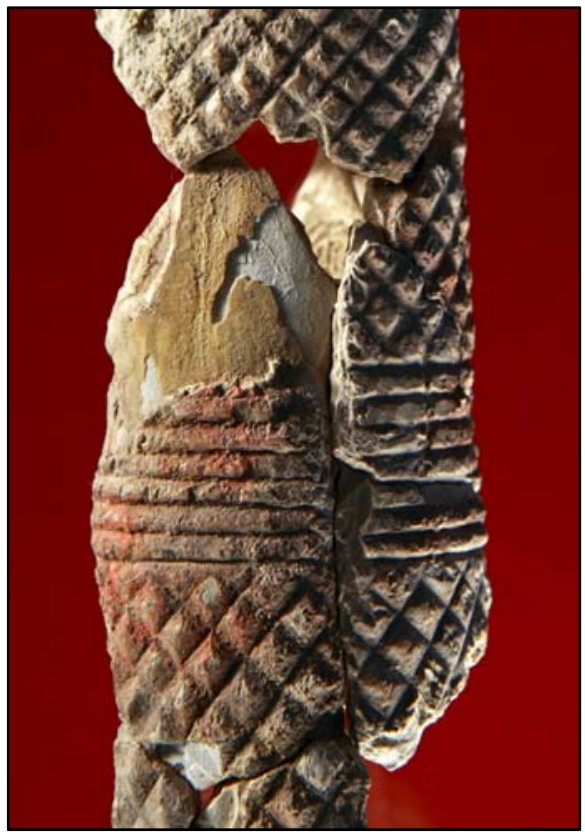

Figure 09: Carved elephant tusk: details of the decoration. Remains of cinnabar pigment can be seen on the left hand side. Photograph: Miguel Ángel Blanco de la Rubia.

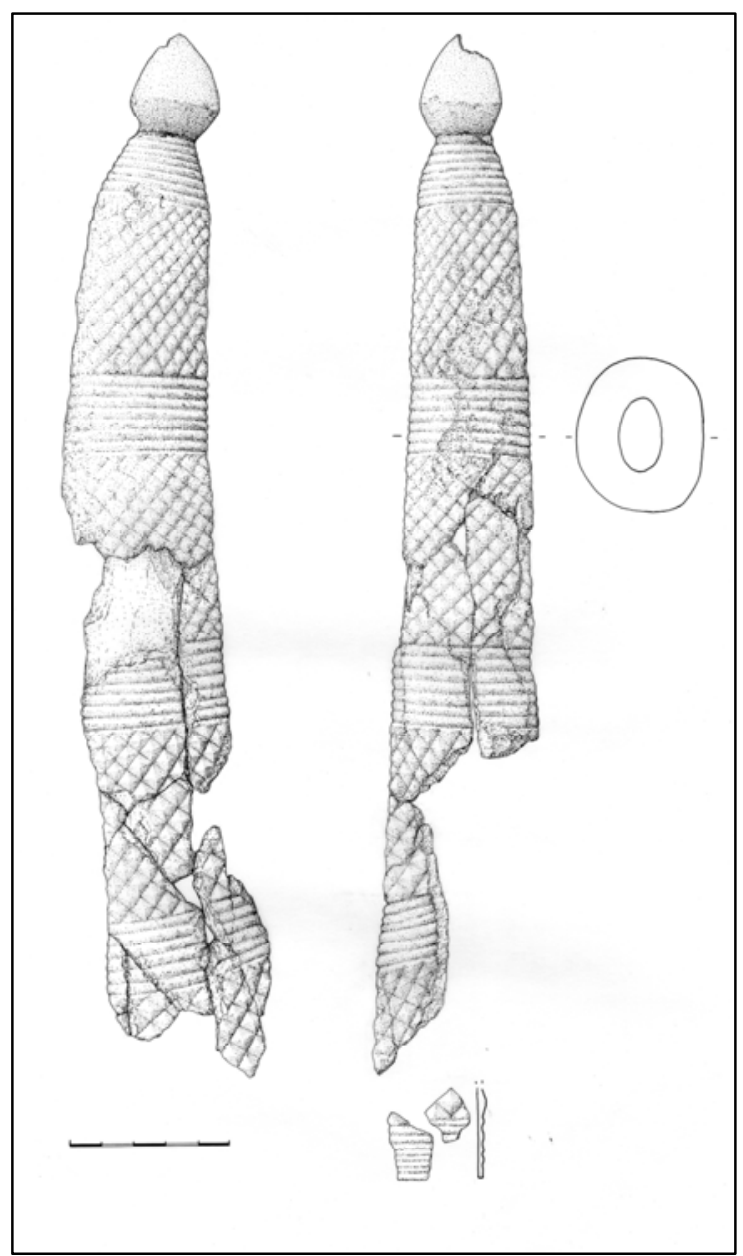

Figure 10: Carved elephant tusk. Drawing by Elisabet Conlin. 


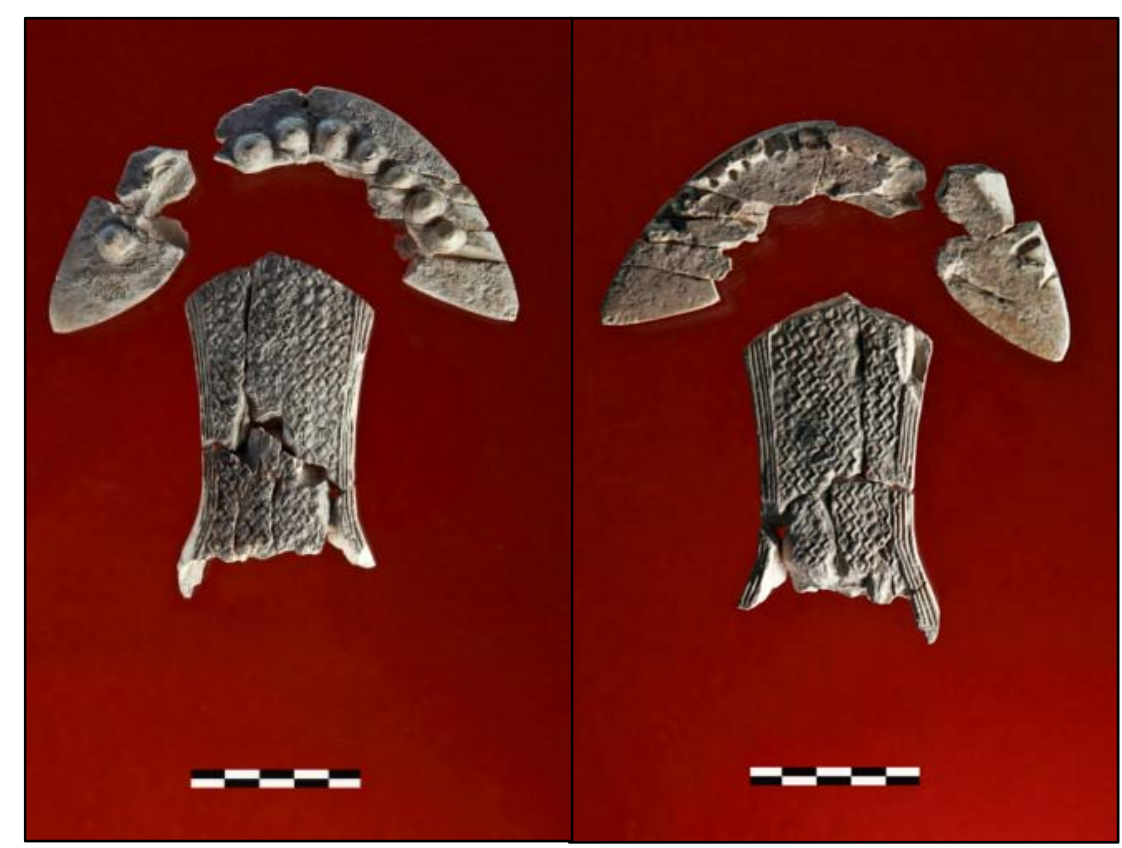

Figure 11: Dagger hilt: anverse (left) and reverse (right). Photograph: Miguel Ángel Blanco de la Rubia.

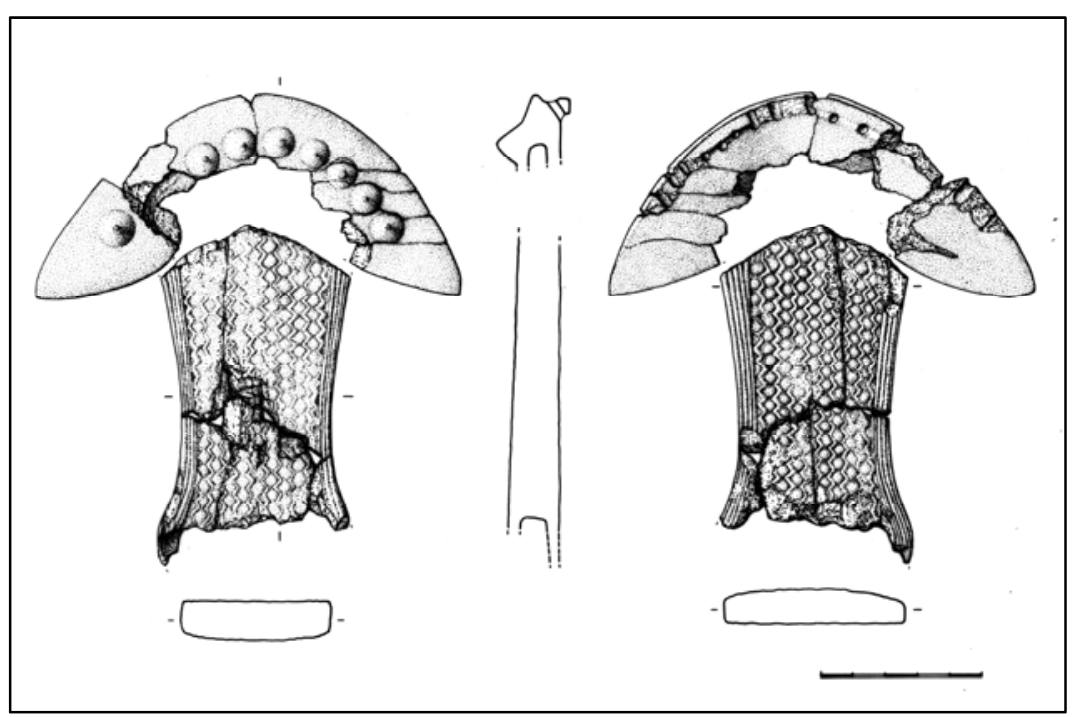

Figure 12: Dagger hilt. Drawing by Elisabet Conlin. 


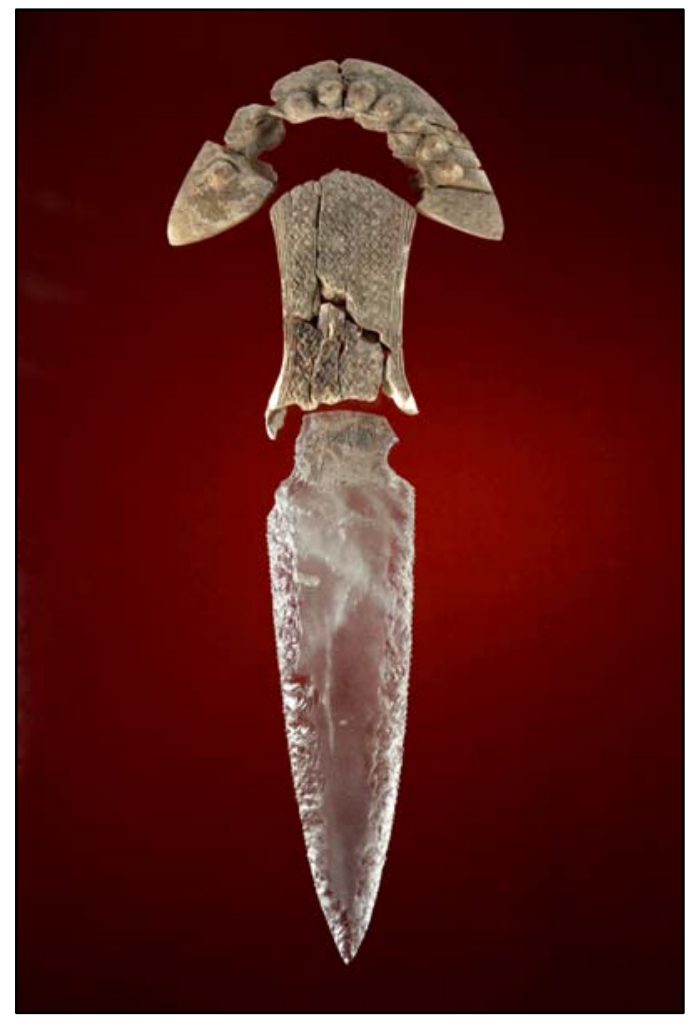

Figure 13: Dagger hilt with rock crystal blade. Photograph: Miguel Ángel Blanco de la Rubia.

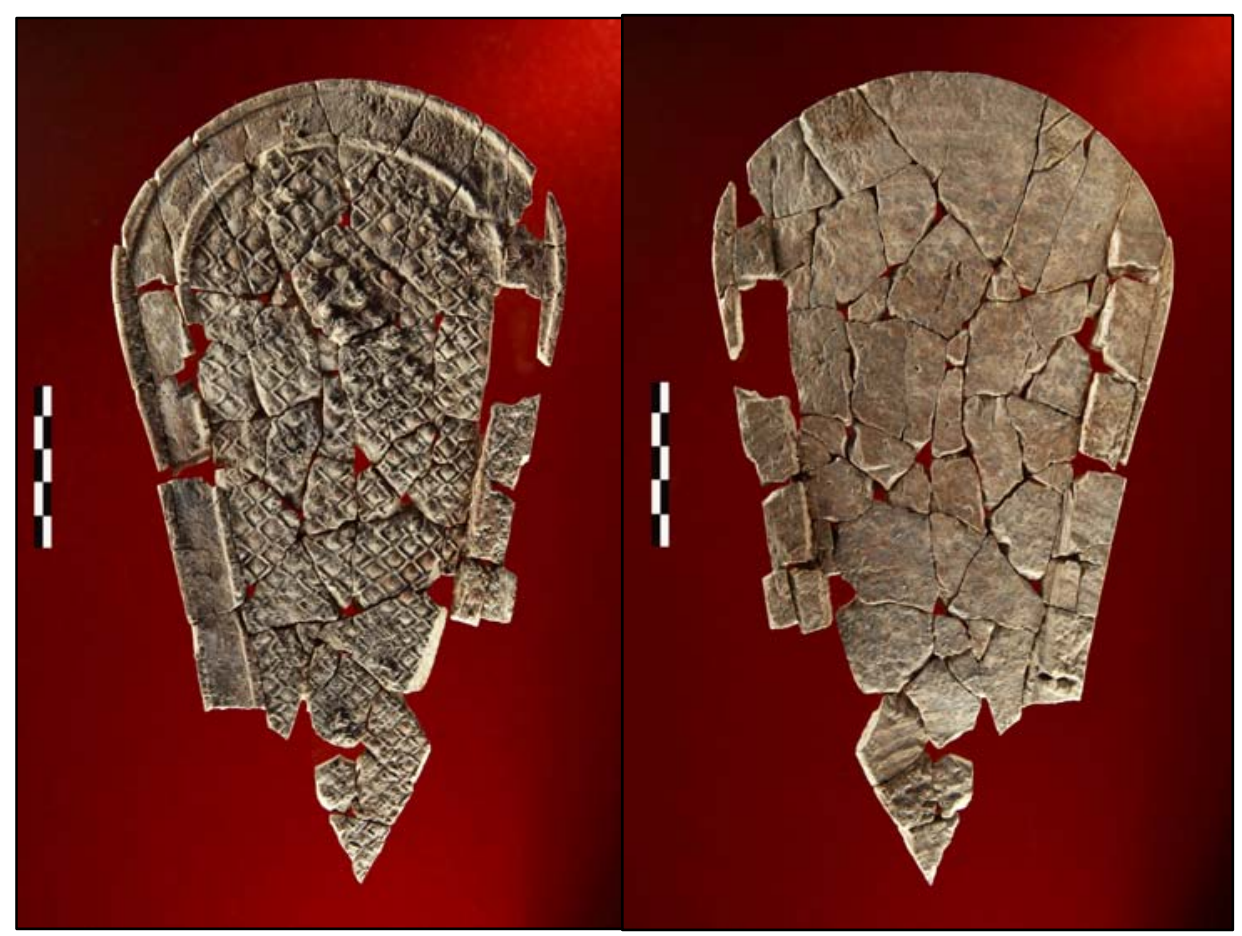

Figure 14: Carved plaque or sheath: (left) and reverse (right). Photograph: Miguel Ángel Blanco de la Rubia. 


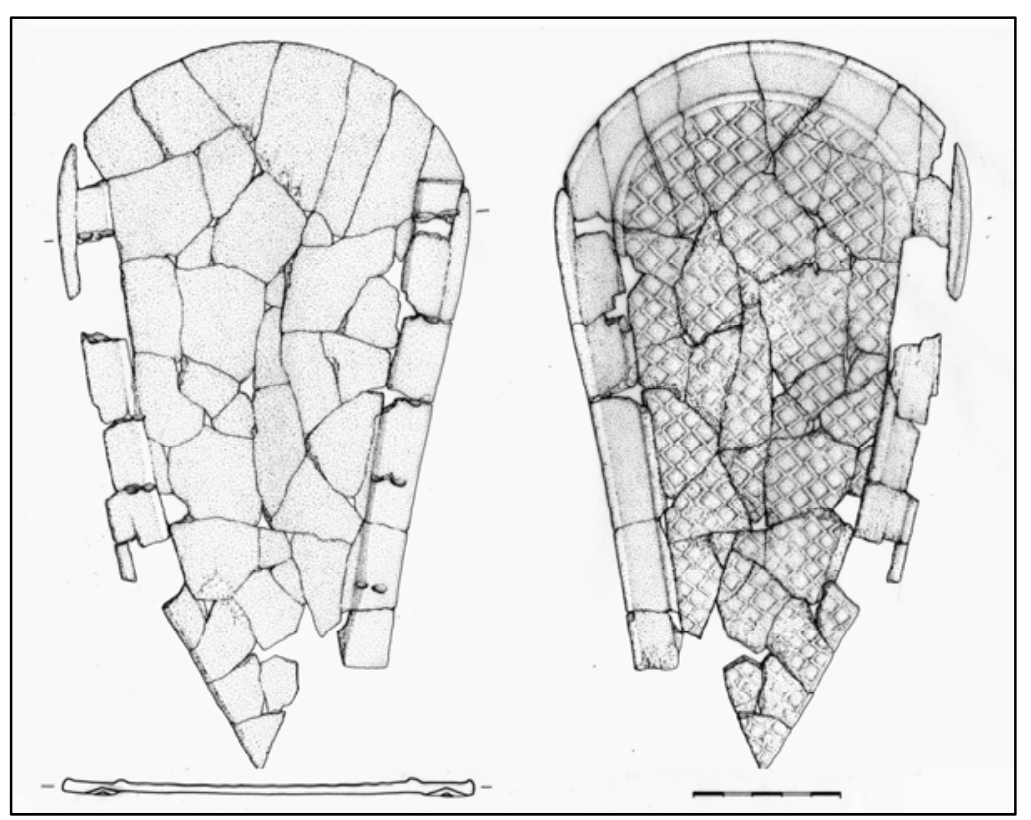

Figure 15: Carved plaque or sheath. Drawing by Elisabet Conlin.

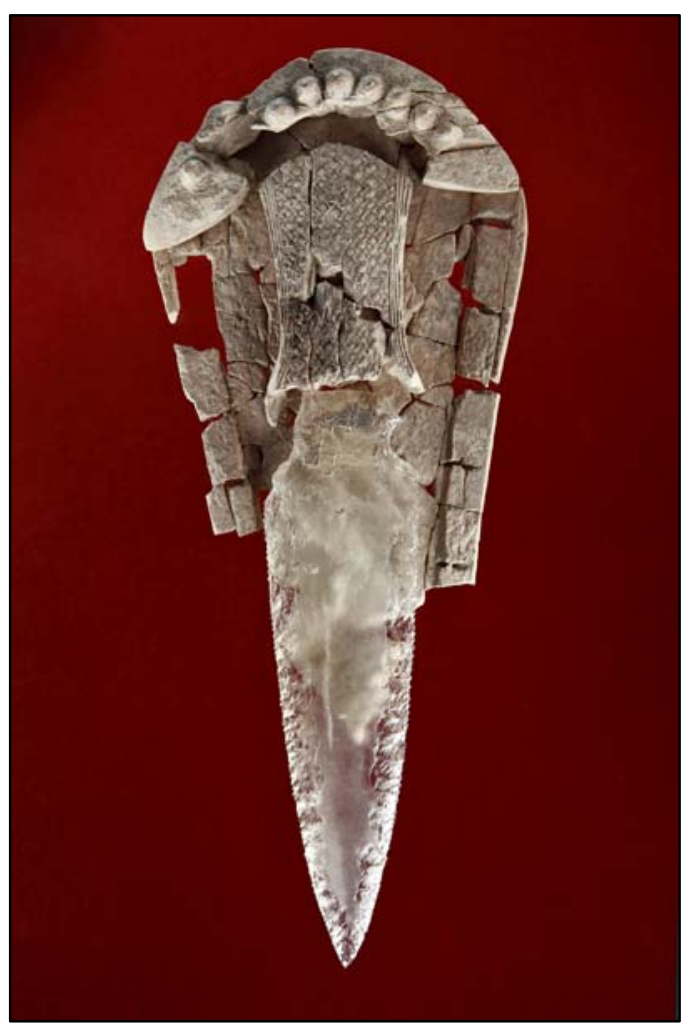

Figure 16. Dagger hilt with rock crystal blade and sheath. Photograph: Miguel Ángel Blanco de la Rubia. 


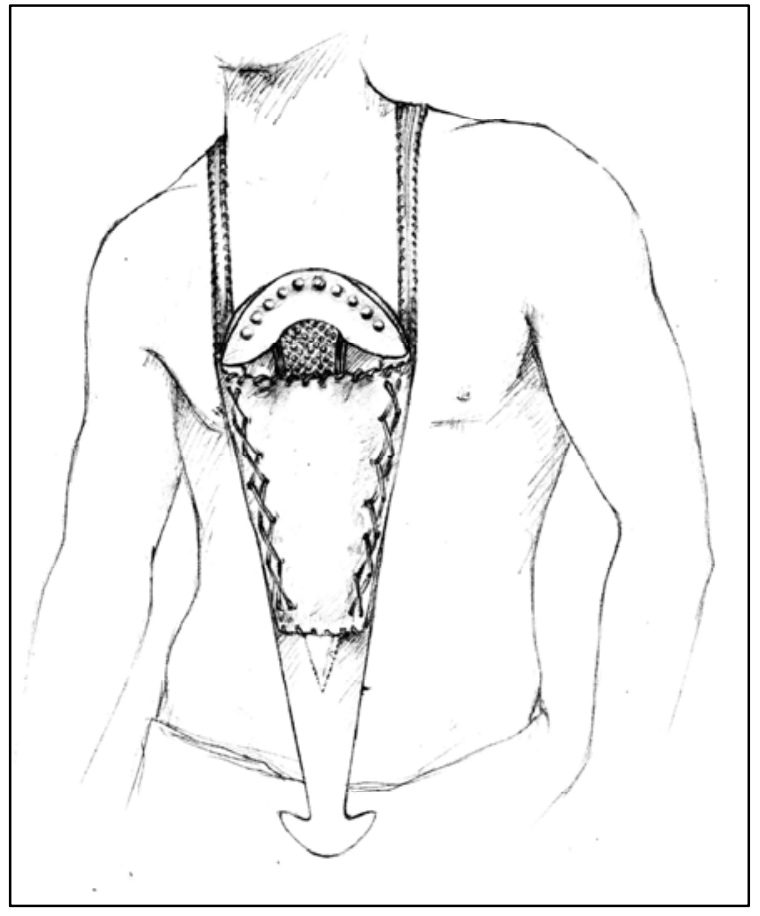

Figure 17. Idealised reconstruction of the suspension system for the dagger, partly based on data from southern Portuguese Early Bronze Age stelae. The chosen model is a young male, following the anthropological characterisation of the individual found at the lower (earlier) depositional level of the main chamber of tomb 10042-10049. Drawing: Miriam Luciañez Triviño.

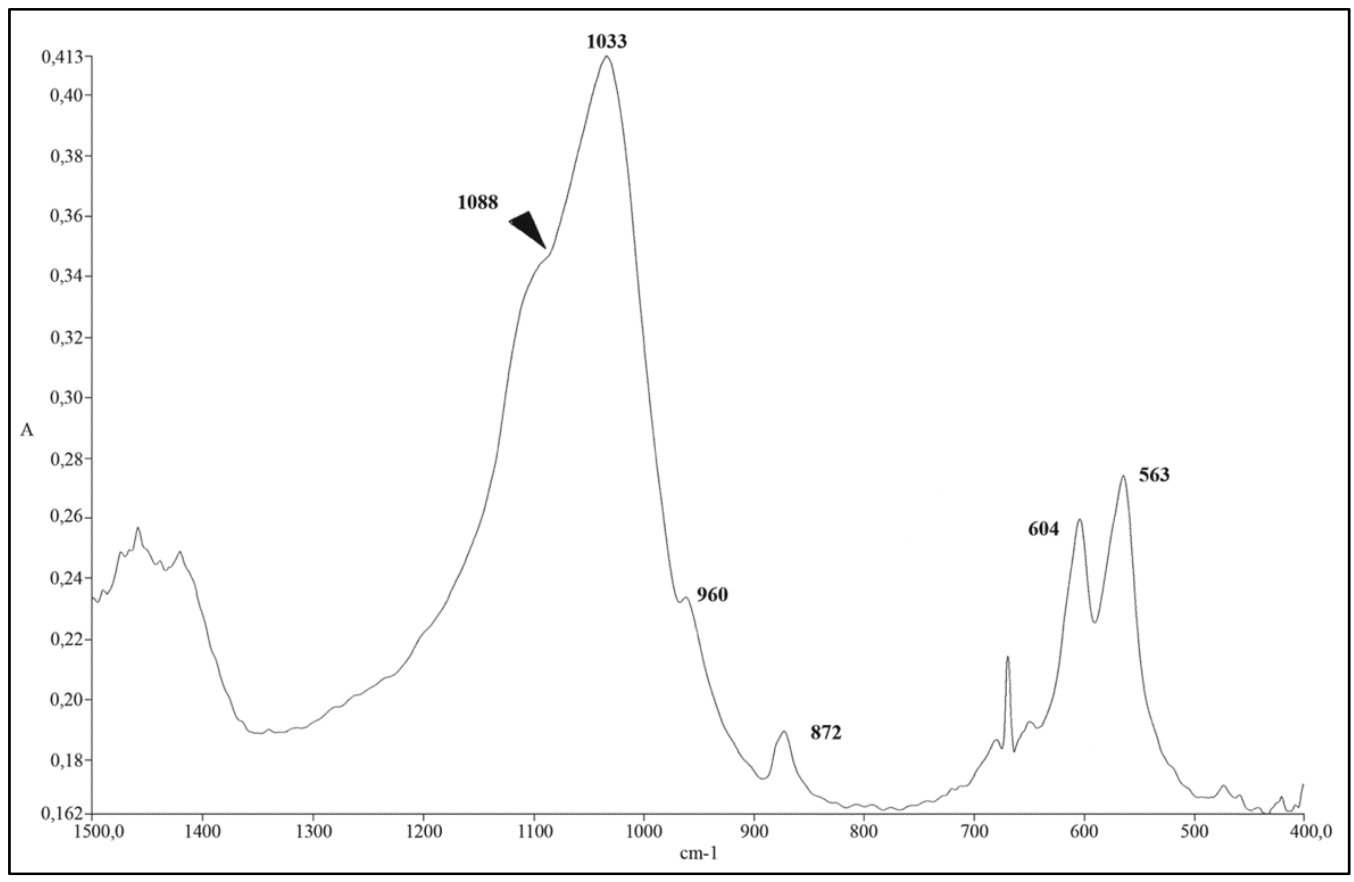

Figure 18. FTIR spectrum (Absorbance) from 1500 and $500 \mathrm{~cm}^{-1}$ of sample Elf 766 . This spectrum, as well as the FTIR spectra of other samples, match with the Standard FTIR spectrum (FTIR database) of Elephas maximus (Asian elephant). 


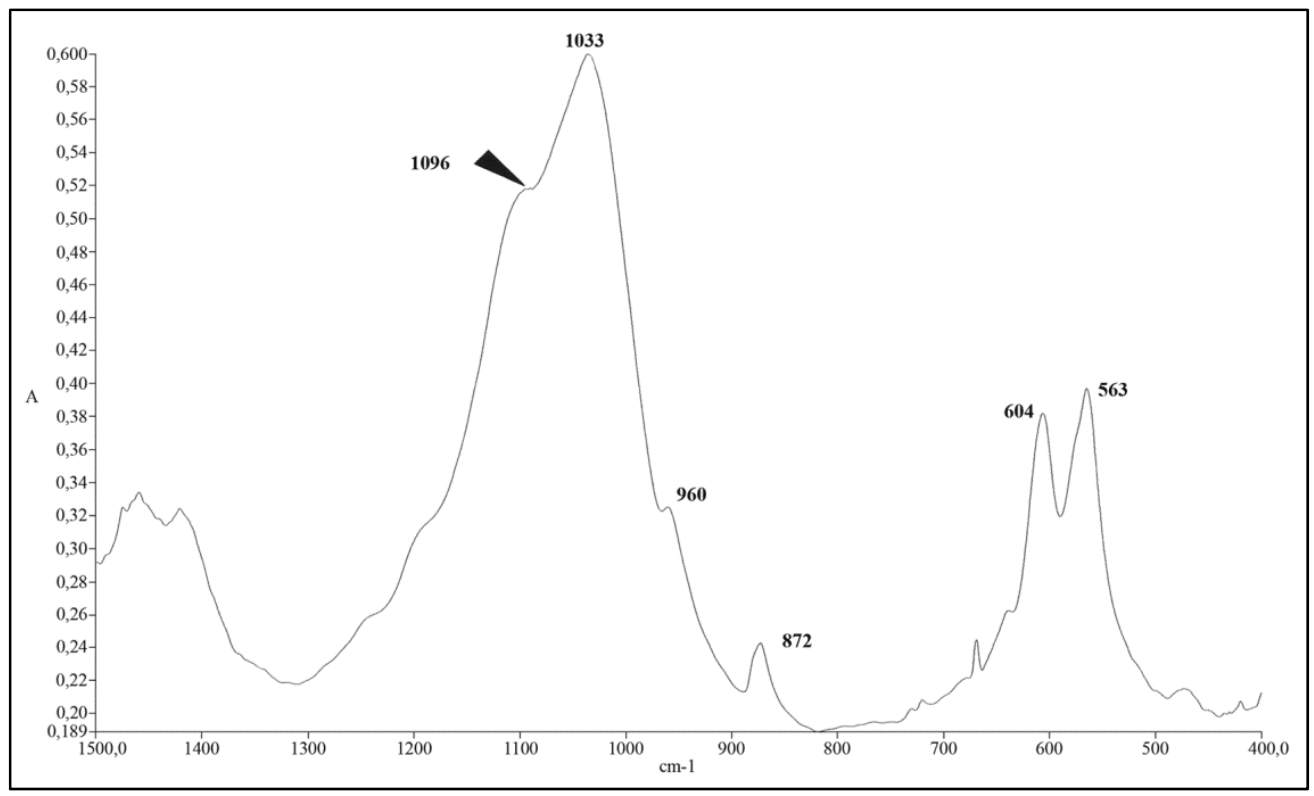

Figure 19. FTIR Spectrum (Absorbance) in the region 1500 and $500 \mathrm{~cm}^{-1}$ of sample Elf 727 . This spectrum, as well as the FTIR spectra of other samples, match with the standard FTIR spectrum (FTIRdatabase) of Loxodonta africana (African savannah elephant).

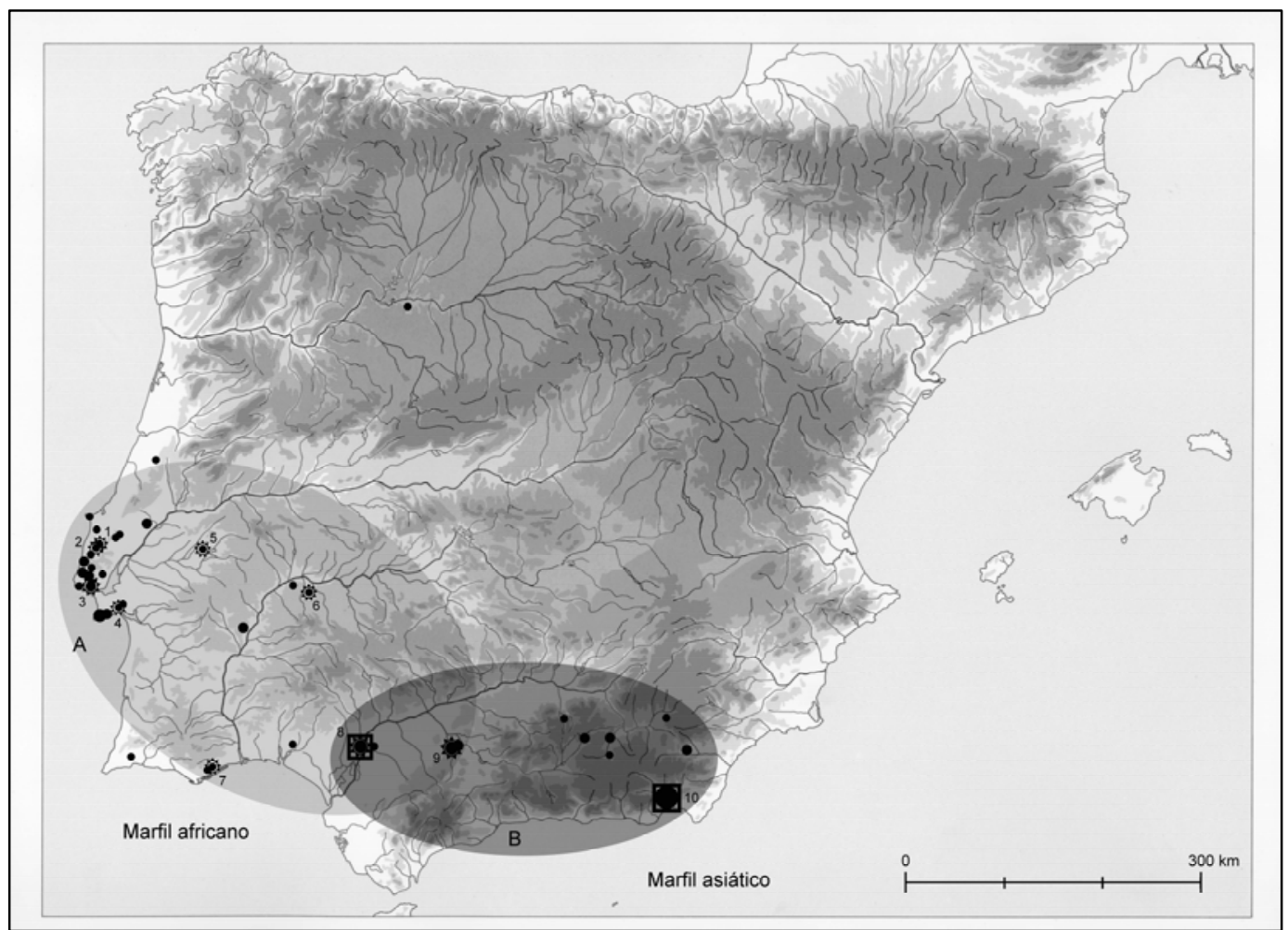

Figure 20. Distribution map of ivory objects during the early Chalcolithic (first half of the $3^{\text {rd }}$ millennium BC): 1 Cova da Moura; 2 Zambujal; 3 Leceia; 4 Palmela; 5 Anta da Herdade da Capela; 6 La Pijotilla; 7 Nora; 8 Valencina de la Concepción; 9 Cueva Antoniana (Gilena); 10 Los Millares. Ivory of African Savannah Elephant; Ivory of Asian Elephant. 


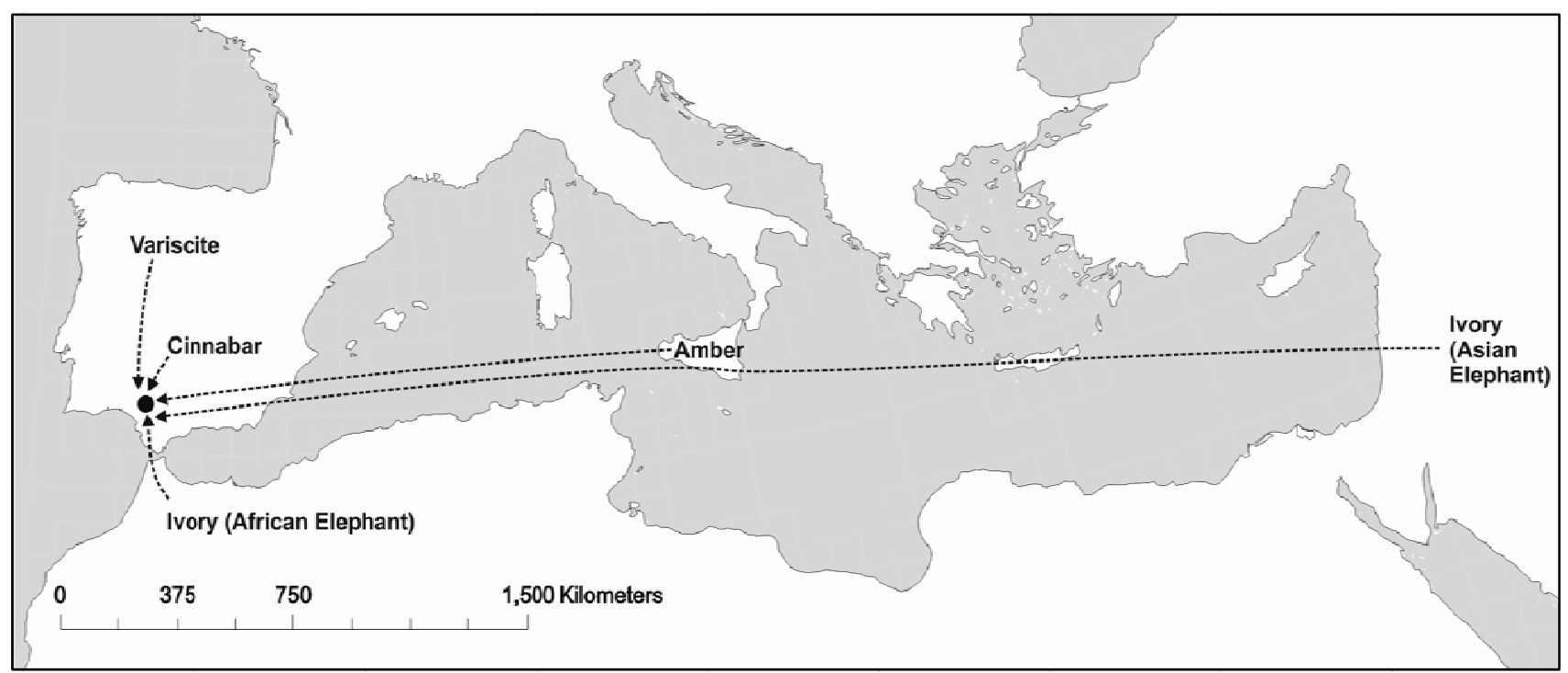

Figure 21. Synthethic map showing the provenance of foreign objects found at Valencina de la Concepción. 